\title{
Article \\ Complex Valuation of Energy from Agricultural Crops including Local Conditions
}

\author{
Václav Voltr ${ }^{1, *} \mathbb{B}$, Martin Hruška $^{1}$ and Luboš Nobilis ${ }^{2}$ \\ 1 Institute of Agricultural Economics and Information, 12000 Praha 2, Czech Republic; hruska.martin@uzei.cz \\ 2 ECO Trend s.r.o., 14700 Praha 4, Czech Republic; nobilis@ecotrend.cz \\ * Correspondence: voltr.vaclav@uzei.cz; Tel.: +420-60-773-7414
}

Citation: Voltr, V.; Hruška, M.; Nobilis, L. Complex Valuation of Energy from Agricultural Crops including Local Conditions. Energies 2021, 14, 1415. https://doi.org/ 10.3390/en14051415

Academic Editor: Vitaliy Krupin

Received: 31 December 2020

Accepted: 27 February 2021

Published: 4 March 2021

Publisher's Note: MDPI stays neutral with regard to jurisdictional claims in published maps and institutional affiliations.

Copyright: (c) 2021 by the authors. Licensee MDPI, Basel, Switzerland. This article is an open access article distributed under the terms and conditions of the Creative Commons Attribution (CC BY) license (https:// creativecommons.org/licenses/by/ $4.0 /)$.

\begin{abstract}
This paper provides values of economic, energy and environmental assessments of 20 crops and assesses the relationships of soil-climatic conditions in the example of the Czech Republic. The comparison of main soil quality indicators according to the configuration of land and climate regions is performed on the basis of energy and economic efficiency as well as a comparison of the level of environmental impacts. The environmental impacts are identified based on the assessment of emissions from production and also in the form of soil compaction as an indicator of the relationship to soil quality. As concerns soil properties, of major importance is soil skeleton, slope of land and the depth of soil, which cause an increase in emissions from the energy produced. Substantially better emission parameters per $1 \mathrm{MJ}$ through energy crops, the cultivation of perennial crops and silage maize has been supported. Among energy crops, a positive relationship with the quality of soil is seen in alfalfa, with a significant reduction in soil penetrometric resistance; energy crops are also politically justifiable in competition with other crops intended for nutrition of population. The main advantage of energy crops for the low-carbon economy is their $\mathrm{CO}_{2}$ production to $\mathrm{MJ}$, which is almost half, especially in marginal areas with lower soil depths, slopes and stoniness, which can be included in the new agricultural policy.
\end{abstract}

Keywords: energy crops; gross margin; local conditions; climate; soil; modeling; LCA

\section{Introduction}

The relationship between food production, energy and the environment is currently an essential issue faced by agriculture [1]. Soil as a means of crop production is subject to many relationships associated with nutrition of population, environmental cleanliness as well as the need to ensure a sustainable source of energy [2]. The problem is escalating due to the necessity to secure food for the growing population [3-5], while responding to changes in farming conditions as a result of climate change [6,7]. A need arises to more accurately specify the production that will be politically justifiable. It turns out that the priority for political decision-making is the food and nutrition security of the population, but a wide-ranging discussion has emphasized the additional potential of energy generation from agricultural products. The entire process has not been adequately specified as yet due to insufficient knowledge of the context of agricultural production with regard to the referred to aspects and diverse conditions [8]. Discussions have been opened up on the use of straw for energy purposes [9], but there are also other matters to be addressed apart from the sufficient volume of production, which also concern the organic matter in soil [10,11].

Agricultural production has diverse impacts on the environment, economy and energy production depending on the relevant conditions [12]. Determination of soil and climatic conditions for crop production and their impact on energy and the environment are crucial for drafting the supporting documents for the purpose of analyzing the relationship between the energy production possibilities and the environment as well as for agricultural policy-making. The existing data provide good quality information regarding the individual crops in the form of a case study helping to identify mutual relationships. However, a 
systematic overview of crop production as a whole, including energy production and links to the environment, is missing. The submitted paper uses the comprehensive information on land resources in the Czech Republic and draws up mutual interactions of economic and energy nature that are dependent on the main characteristics of climatic and soil conditions in the Czech Republic. The paper determines the energy and economic margin based on the cost-benefit analysis by crop production technology, and also a comprehensive relationship to the environment based on the life cycle assessment (LCA) analysis for a total of $18 \mathrm{im}-$ pacts in line with the midpoint analysis. Matters of evaluation of production with respect to decision-making on support, location and potential of agricultural crop production also for energy generation are addressed by numerous recent publications [13-15]. Multiple issues arise that are difficult to resolve by the agricultural policy unless the main economic, energy and environmental context is known well in advance [8].

These matters are extensively covered by the literature. Nonetheless, for the evaluation of all relationships, no comprehensive data are available on the entire territory and production structure. These issues are therefore mostly reflected only with respect to the production of one or more crops based on a model solution or a case study [14].

All the explored parameters, namely the economic, energy as well as environmental parameters, should be subjected to a comprehensive analysis in order to find the optimal future use of crops. Razm [16] in his production assessment used the LCA model in order to achieve the Pareto optimality in assessing the environmental and social impacts of crop production. This procedure can also be applied to seeking the optimal production when making decisions on the use of biofuels.

Some countries have searched for the missing framework for crop production assessment-e.g., development of supporting documents for agricultural crop production in Denmark should be based on a review and an assessment of publicly available databases, inventory reports and scientific literature on measures in the field of governance and their effectiveness with respect to legislation, agreements, conventions and standardizations (Bentsen [17]). The main reason behind this is the necessity to promote the environmental sustainability represented by greenhouse gas emissions from the agricultural sector, soil carbon sequestration, water quality, and biological diversity.

The bioeconomy plays an important role in replacing fossil fuels and is the key factor for sustainability. Wohlfahrt [8] stresses the socio-ecological concept of its exploration, the importance of knowledge of individual territories, flexibility of business activities of subsystems and local regulatory instruments. This justifies the necessity to develop an integrated model approach with various subsystems and heterogeneity. This builds on the assessment of agricultural land composition and its configuration.

\section{Materials and Methods}

The energy plan of the Czech Republic provisionally estimates that with a decrease in the production of biofuels from 11,093 TJ in 2020 to $9276 \mathrm{TJ}$ in 2030-i.e., a decrease by approximately $15 \%$ - that biogas production should fall from 22,856 to 20,166 TJ-i.e., by $12 \%$ [18]. This plan states that the value of agricultural production is very uncertain in the future and depends mainly on the setting of the rules of the Common Agricultural Policy (CAP). Further development of the trend is based on a careful evaluation of all aspects of energy production, including in terms of the function of energy production in the landscape. 
Overall energy effectiveness of production is conditional on the choice of crops in the given location, while respecting local conditions which depend on the particular type of farming of agricultural holdings and may vary according to the needs of animal production. Fundamental studies necessary to derive energy indicators have been addressed by a number of authors [19-21], and data for the Czech Republic from the IAEI survey and Preininger [22] were used in this analysis.

In the Czech Republic, a permanent monitoring system of agricultural production was developed based on the evaluation of evaluated soil ecological units (ESEUs, in the Czech Republic called BPEJ, introduced in the Czech Republic in 1970). The system is based on the classification of climatic factors within the climatic region (Appendix C, Table A2, the main soil unit (MSU (HPJ)), describing the main pedological characteristics of soil, and on the description of terrain configuration: slope $\left({ }^{\circ}\right)$, deep of the soil $(\mathrm{cm})$, stoniness (\%), and by the area in the Czech Republic [23]. MSUs are laid down in a decree [24], but more information is provided by the tracking of the Research Institute for Soil and Water Conservation [25]. In the Czech Republic, a total of 2199 ESEUs have been classified that are mutually compatible throughout the territory of the Czech Republic. Based on the definition of these units, a paper was elaborated in order to cast more light on the links between the production and soil-climatic conditions-e.g., the modification of economic indicators based on production functions [26]. Even though the evidence of ESEU is domestic, the obtained generalized information can also be used for assessments in other countries.

Environmental indicators are essential to assess any production. The LCA assessment of crop growing impacts is described, e.g., by [27-30], and preparations are carried out for individual evaluation of technologies for the size of emissions, especially $\mathrm{CO}_{2}$ [31].

This study is based on the values included in the Agri-footprint 4.0 database [32] and impact categories of the ReCiPe method were used. Model processes, based on Agrifootprint database processes, were modified on the basis of specific data for the Czech Republic. The adequacy of the modified processes was verified by comparison with the results of the original Agri-footprint processes and the Ecoinvent 3 database.

The data included in the national database of soil economic information were used to set the main yields and inputs and are subsequently updated in line with the soil and climatic conditions in the Czech Republic. The statistical survey is based on a sample cost survey of approximately 250 agricultural enterprises and the results are processed according to the IAEA methodology [33,34].

Information on crop yields and costs on individual soil-climatic conditions was used to calculate total emissions in individual categories according to the Agri-footprint database [32] and to calculate crop production in MJ. The resulting ratio was assessed against the description of soils in the Czech Republic [35].

The current papers add more information on ESEU and thus offer a comprehensive picture of mutual inter-relationship of economic, energy and environmental aspects [36-38]. Figure 1 shows a comprehensive monitoring system based on available data, which are validated and specified against individual ESEUs. The diagram shows the sources for processing the economic and energy data of crop yields, technologies and their costs as well as the composition of crops, including links to the calculation of emissions from Agri-footprint data.

The main scheme of calculation is given in Appendix A. It is used to calculate the economic, energy and environmental data.

The basic approach consists in the cost-benefit analysis of production of individual crops. 


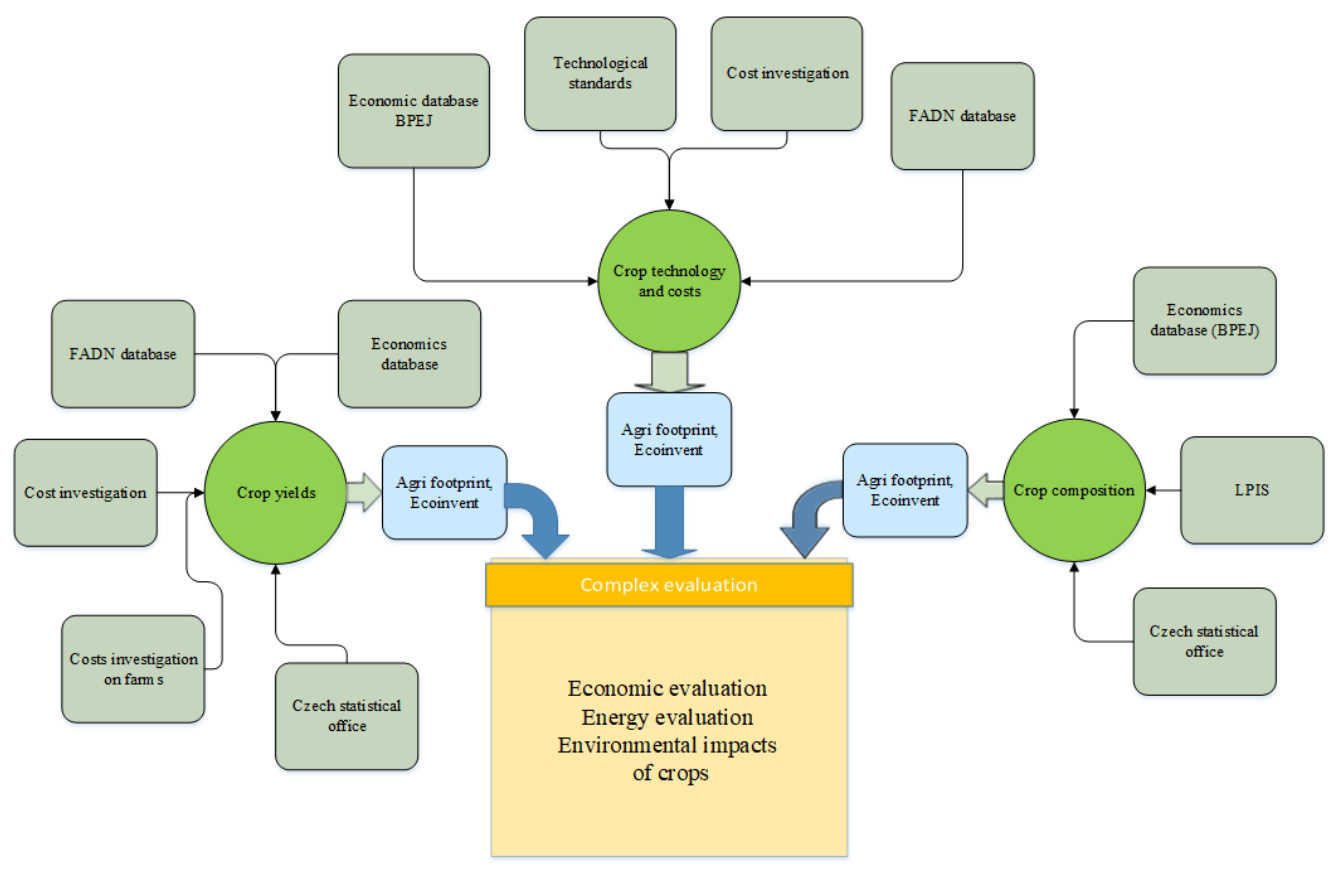

Figure 1. Processing of economic, energy and environmental data for calculation.

\subsection{Method to Determine the Economic and Energy Values}

When assessing the production, the indicators of economic and energy gain (Gross margin including overheads) were determined based on the production value once the necessary operating and overhead costs were deducted [39].

$$
G M o_{i, p}=S O_{i, p}-\text { COGSo }_{i, p}
$$

where: $G M o_{, i, p}$ is a Gross Margin with overheads for crops $p$ and soil-climatic conditions $i$, COGSo $=$ cost of goods sold including overheads $\left(\mathrm{EUR}^{\mathrm{h}} \mathrm{ha}^{-1}\right)$ and $\mathrm{SO}$ is a standardized output of crop products (EUR $\cdot \mathrm{ha}^{-1}$ ). More details are provided in Appendix B.

This procedure was opted for due to the need to calculate the total costs of production for the purpose of assessing the economics of farms according to individual crops by the Institute of Agricultural Economics and Information (IAEI) and it is reflected in all the supporting documents [40].

The overheads are derived from the economic data on agricultural holdings ascertained by the IAEI survey and, with respect to energy, the same value was used as the costs of working operations in in the overhead costs to direct variable crop production cost ratios. The reason thereof is primarily the burdening of production of some crops (e.g., potatoes) with high overhead costs of postharvest treatment and storage.

The market price of agricultural production resulting from the IAEI statistical survey and the resulting price depends on the yields corresponding to the given soil and climatic units according to ESEU.

Energy gross margin including overheads 2 is similar:

$$
E G M o_{i, p}=E N S_{i, p}-E C O G S o_{i, p}
$$

where: $E G M o, i, p$ is the energy gross margin with overheads for crops $p$ and soil-climatic conditions $i, E C O G S o$ = energy of cost of goods sold (GS) including overheads (Tables A4-A7 MJ) and ENSi,p is the standardized output in MJ (Table A3).

The energy values of $E G M o, i, p$ production were evaluated on the same inputs and outputs as GMo (1). The primary energy values of the costs are derived from weight of the machines in kilograms listed in the database according to the example in Table A1, where the weights (in kilograms) of machines needed for the production inputs are described. 
The value of primary energy per kilogram of weight (Table A5) is divided by the number of years of depreciation and by the number of hectares processed per year. Energy of fuel (Table A6) is given by fuel consumption for work operations and for maintenance on the basis of fuel consumption equivalent, fuel consumption for the transport of materials and technological equipment, according to the energy of organic and inorganic fertilizers (Tables A6 and A7) [34], and protective equipment [41]. The costs were calculated by the Institute of Agricultural Economics and Information (IAEI) [36]. The costs of transport of material were calculated for the standard distance of $5 \mathrm{~km}$ between the farm and the land. The calculation of costs also included the labor costs based on the average labor rates in agriculture in the last 5 years.

Soil conditions were determined by soil classification in the ESEU system. Data on slope, soil depth and percentage of stones over $2 \mathrm{~mm}$ in the soil were evaluated in the physical units.

The economic values of yields and inputs into the soil for soil-climatic conditions in the Czech Republic were compiled according to the database of ESEUs rated [33,35,36]. Earlier data on revenues for ESEU based on the data of 1970 have been updated by a detailed survey of 529 plots conducted over a period of 9 years (2002-2010). The yield (Y) design was based on the production functions of the dependence of yields on natural and technological conditions [38] according to Equation (3).

$$
Y=f(W t ; S ; Z ; P ; L ; T)
$$

where $Y$ : yield of crops, $W$ : variables of temperature, precipitations and soil moisture, $S$ : soil type, sort and conditions, Z: nutrition of nitrogen, phosphorus and kalium; $P$ : number of chemical protection operations, $L$ : cultivation of soil and $T$ : progress of technology.

The underlying values for yields and similarly for nitrogen dosing and the chemical treatment application were compiled according to the statistical valuation of the given environmental conditions [39].

According to the identified functions, the yields were standardized to the remaining soil-climatic conditions. Subsequently, the proposed value of standard yields was validated with the current value of yields under the given conditions, and a new standardized value of yields was proposed for ESEU. A similar function such as the derivation of the yield (Relationship 3) was compiled by the dependence of nitrogen doses on soil-climatic influences.

An example of a comparison of actual and standardized results of production functions for yield of winter wheat is shown in Figure 2.

The compiled standardized yield values correspond to the categories of soil-climatic conditions for which the values are determined. The climatic factors that are most important for the achieved yields are therefore always calculated for the relevant classification scale and its values-i.e., for climatic regions 0-9 (Table A2). When evaluating specific yield conditions, there is always a deviation from the standardized values due to the achieved weather values, which similarly applies to the monitored soil values. Nevertheless, the database is based on the balanced properties given by long-term observation and statistical analysis of individual effects. For the purpose of this article, the data are sufficiently informative even if they do not meet the requirements of directly measured values, and thus the statistical results are affected by a certain similarity of climatic and soil influences within specific groups of conditions. 


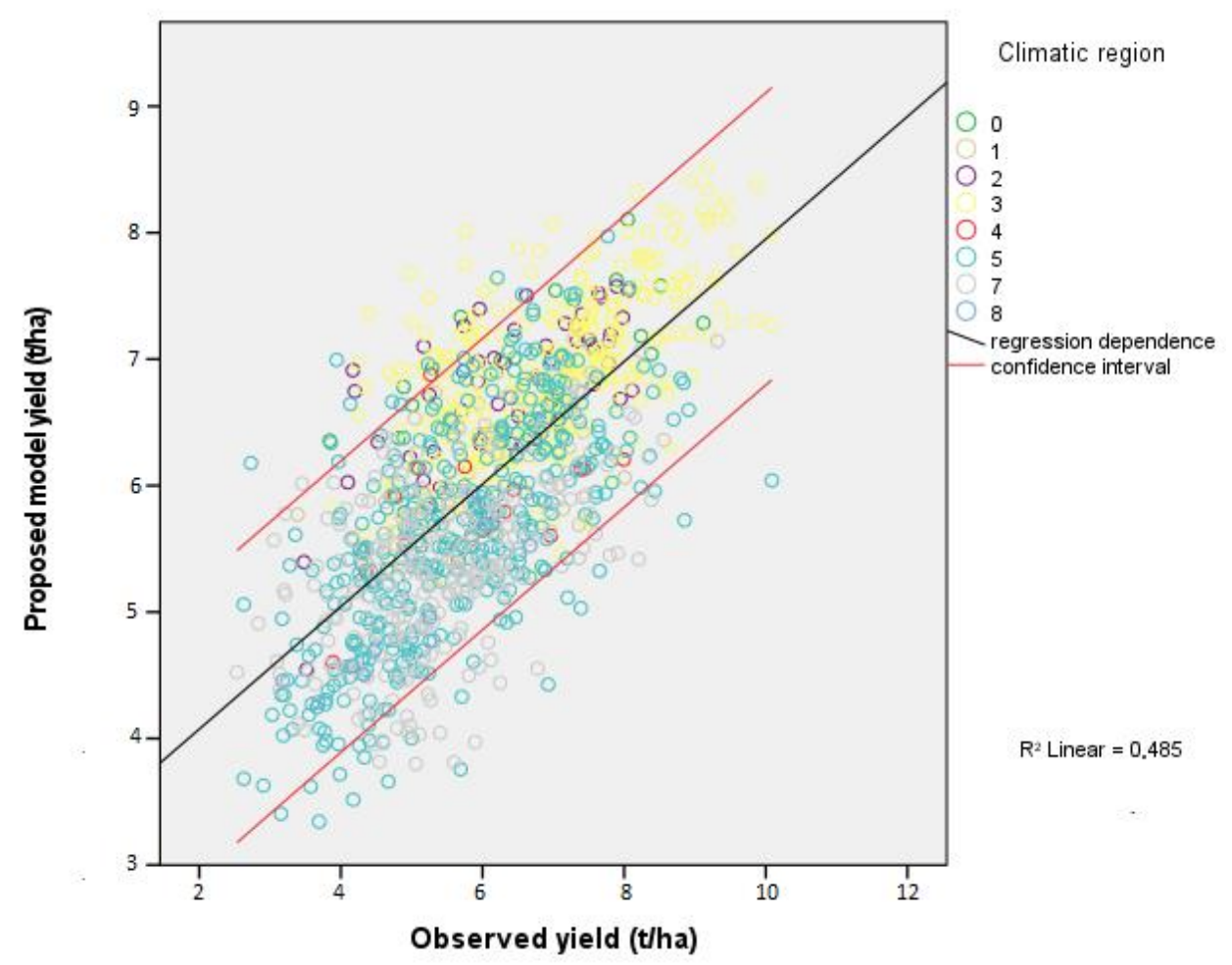

Figure 2. Comparison of winter wheat yields and yield prediction using the production function [38].

For the economic evaluation of the cultivated crop, the economic efficiency $\eta E p$ was determined according to the Equation (4).

$$
\eta E p_{i, p}=S O_{i, p} / \text { COGSo }_{i, p}
$$

as the ratio of the value of output (SO) to the value of input (COGS).

Energy efficiency $\eta E n p$ is computed similarly in Equation (5).

$$
\eta E n p_{i, p}=E N S_{i, p} / E C O G S o_{i, p} .
$$

\subsection{Assessing the Environmental Impacts of Crop Production}

The assessment comprises the methods determining the formation of emissions from crop production on soil, water and air as well as physical impacts of production on the quality of soil in the form of soil compaction.

Determining the Formation of Emissions on the Environment

The content of the evaluation in this article is mainly the ratio of individual types of emissions and the achieved energy of outputs, which evaluates the relationship of individual ESEUs and crops to emissions. The main indicator assessing the environmental impact of production used in this paper was the ratio of total emissions of individual types of indicators to the total crop production including the by-product [42].

Environmental impacts were added on the basis of a description of specific emissions (midpoint) and the system allows global life cycle impact (endpoint) for selected crops [39]. Values are based on the results of the ReCiPe method assessment of primary data for the Czech Republic and the secondary results are based on the Agri-footprint LCI database.

In this context, the stages of the product life cycle are divided into: upstream-processes preceding the actual manufacturing of the product, core-actual manufacturing of the product and downstream-processes following the manufacturing of the product. 


\subsection{Model Processes to Determine Emissions}

The model processes are based on the Agri-footprint database; they were modified using the specific data of IAEI and are based on the data for energy evaluation-the weight of machinery, repairs (equivalent in 1/ha of consumed diesel), transport costs (energy requirements of transport in $\mathrm{MJ} / \mathrm{ha}$ ), consumption of fuels and chemical protection (necessary technology in MJ/ha and weighted dose of pesticides in $\mathrm{kg} / \mathrm{ha}$ ) were expressed as diesel consumed by diesel engine of an agricultural machine (energy, from diesel burned in machinery/RER economic) [41,43-45]. The impact of fertilizers was calculated for crop inputs of $\mathrm{N}, \mathrm{P} 2 \mathrm{O} 5, \mathrm{~K} 2 \mathrm{O}, \mathrm{MgO}, \mathrm{CaO}$, and $\mathrm{S}$, and the emissions factors were derived from Agri-footprint database. The emission size relationship is based on the source data of the Agri-footprint database [32,46]. Organic fertilizers were calculated as manure in accordance with the database documents at the level of ESEU. Emissions to air mainly include nitrous oxide, ammonia and pesticide residues, carbon dioxide emissions, which as a reaction of soil with limestone and urea were not included due to the lack of specific data on consumption. Based on the specific data, emissions from minerals, livestock manure and pesticides were recalculated and adjusted. Emissions from crop residues remained the same as in the original process. Emissions to water from mineral fertilizers and livestock manure and pesticides were recalculated and adjusted on the basis of specific data, and emissions from crop residues and heavy metals were assessed according to the original process. Emissions to from soils were based on the specific data; emissions from pesticide residues were recalculated and adjusted and heavy metal emissions were used from the original process.

The ratio of total emissions of individual types of indicators and the energy contained in the total production of the crop, including the by-product, was used as the main indicator for assessing the ecological impact of production. An overview of the average energy efficiency of crops in the Czech Republic is given in Figure 1. To assess the impact of emission to MJ (EmMJ) of produced energy, the specific value of emissions per unit of output energy in MJ 6 was used:

$$
E m M J_{i, p}=E M m i d p_{i, p} / E N S_{i, p}
$$

where EMmidp is the emission of midpoint classifications as a sum of all included partial emissions of operations, fertilization, chemical inputs and transport, for crops $p$ and soilclimatic conditions $i$.

Evaluation of the significance and influence of individual ecological indicators is a separate issue beyond the scope of this work. For their complex evaluation, it is possible to use more methods based on the evaluation of the meaning and weights of individual indicators. Due to the large number of indicators and their various possible interpretations and due to the simplification of the issue, the methodology of multicriteria decision-making was chosen to determine the total emission value per MJ EEm according to Equation (7)

$$
E E m_{i}=\sum_{E=1}^{k}\left(\sum_{i=1}^{l} E m_{0} / l\right) / k
$$

where $E m_{0}$ is an order of the value of emission for ith crop on ESEU, $E$ is a sort of emission, $k$ is a number of calculated emissions and $l$ is a number of ESEU.

\section{Method of Processing}

Databases are maintained in MS Access and MS SQL databases. For each ESEU, selected technology and crop, standardized values of economic and energy efficiency $\eta E p$ $\eta E n p$ as well as $E m_{0}$ and $E m M J$ for each environmental indicator were processed. 
The supporting documents were elaborated in line with the technological procedures and verified yields of individual crops under the given ESEU. In the system, it is possible to compile procedures for different antierosion methods of soil treatment and for different nitrogen inputs. To compare soil-climatic conditions, the plowing method of tillage was chosen. All individual ESEU categories were always evaluated during the processing. To evaluate the average conditions of crops, weighted averages of indicators of crops were calculated according to the area of ESEU representation in the Czech Republic.

\section{Method of Assessment of Crop Impacts on Soil Environment}

The impact of crops on soil compaction was evaluated from a survey conducted in the years 2002-2011; the assessment of the impacts on soil was based on the penetrometric resistance of soil, which is an appropriate indicator of the overall conditions of agricultural land $[47,48]$, bearing in mind the need to obtain information on deeper layers of soil on large areas. Soil penetrometric resistance is closely related to soil-organic carbon (SOC) formation, where soil resistance decreases with higher soil content [49].

The underlying principles of penetrometer measurements are described in the paper by Lhotský [50]. The methodology has been modified to have one sample point for approximately 5 ha. There were three sample points on a plot with the area of up to 10 ha, with another sample point that always added an additional area of up to $5 \mathrm{ha}$; the sufficient number of sample points, however, was 10 . The location of these points was chosen so that they were equally distributed across the entire land plot and were not located in the headland. During each measurement, the probe was pushed into the soil at a constant speed and the penetrometer was reset in cases where the probe hit a stone. Soil samples were collected in each plot in order to determine the soil moisture-namely, from no deeper than the soil tillage depth and from the subsoil layer.

The obtained values of penetrometric resistance are expressed in the form of the mean resistance of three layers-namely, 0-18 cm, 19-38 cm and 39-72 cm.

The results were assessed based on the correlation analysis and show, as well as the direct impact of the crop on the resistance, the general relationships, which determine the effects of penetrometric reistance in the respective soil layers.

\section{Results}

The results of the comprehensive assessment of economic, energy and environmental impacts of crop growing are based on the determination of individual soil and climatic parameters of the locations where the crops are cultivated. Altogether, the assessment covered a selection of 20 crops and different options for their use. The assessment of economic indicators builds on the calibrated economic results of agricultural holdings-namely, on the average of the last 5 years. Therefore, the results are stable and independent of the respective year. The economic and energy indicators are based on the cost-benefit analysis, which facilitates the evaluation of the absolute profit per hectare of the agricultural land in monetary or energy terms. These indicators are shown in the figures and tables as the attained efficiencies according to Relationships (4) and (5). The environmental indicators are related to the produced energy in production including straw.

\subsection{Relation of Economic, Energy and Environmental Characteristics to Soil-Climatic Conditions in the Czech Republic}

To determine more detailed effects of weather and soil conditions in the Czech Republic on the achieved economic, energy and environmental parameters, the available database data of individual crops and environmental indicators in the database were processed. 
The overview of average energy and economic efficiency of crops in the Czech Republic in comparison to $\mathrm{CO}_{2}$ emissions is provided in Figure 3 and Table $\mathrm{A} 8$ and the average terrestrial ecotoxicity values are described in Table A9, with individual data provided in a separated file for all emissions [35].

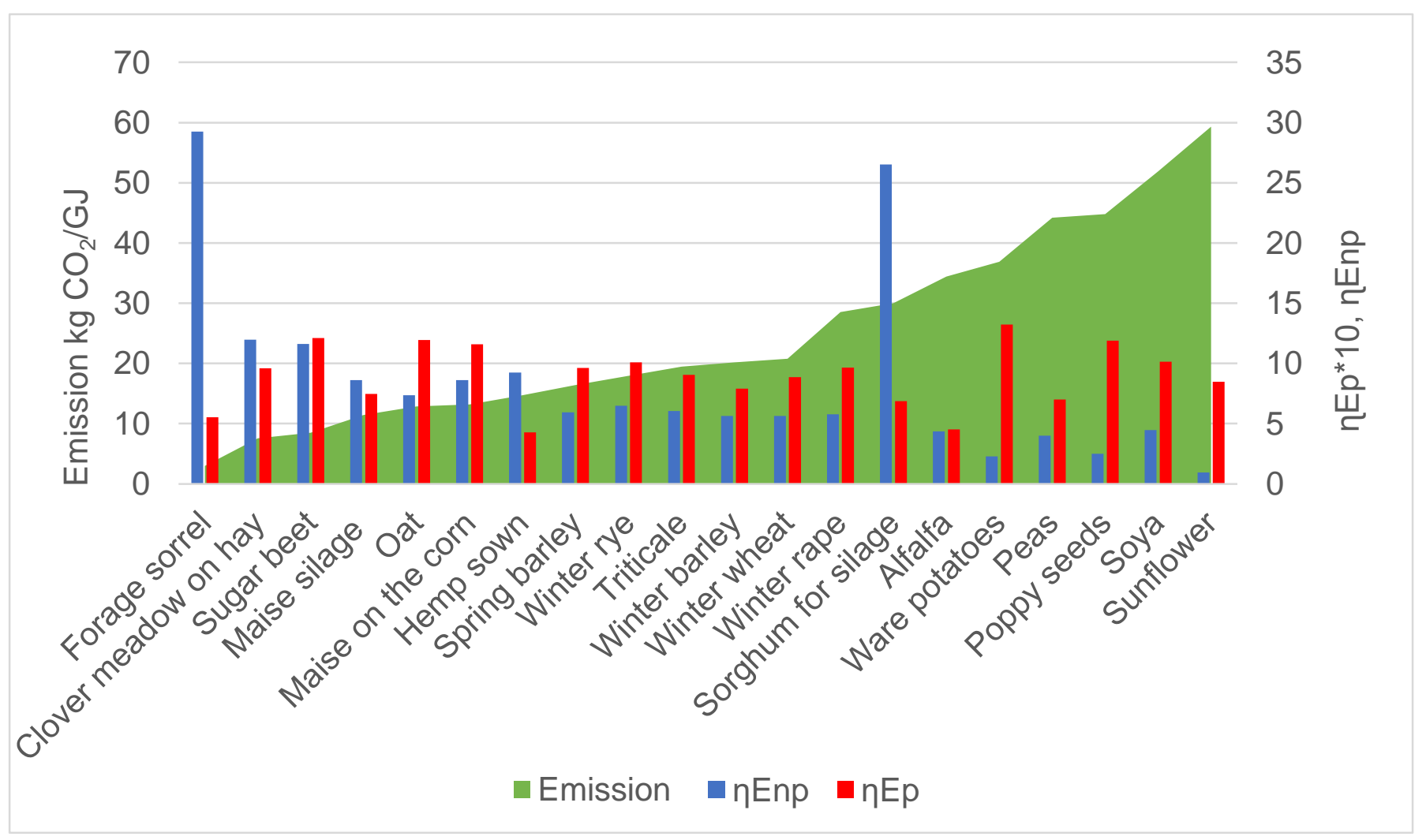

Figure 3. Average values of $\eta E n p, \eta E p$ and $\mathrm{CO}_{2}$ emission per GJ of energy in the product.

The system enables a comparison of results of $\eta E n p, \eta E p$ and EmMJ in the same soil-climatic conditions as well as all the other monitored inputs and outputs. The results of individual crops show the lowest emission load for $\mathrm{CO}_{2}$ per MJ produced for forage bulk crops, the largest load is achieved for crops with food use, where economic efficiency also prevails over energy efficiency. The achieved environmental results depend very much on the technologies used for growing crops and harvesting. For example, alfalfa has almost the same cultivation technology as clover, but its environmental impact reflects a high consumption of diesel fuel, when the silage mass is harvested by high-performance and high-consumption cutters instead of using solar energy for drying. The different value of the energy balance between energy and food crops also provides a new perspective on emissions from animal production, which consumes bulk feeds with better energy efficiency than food production.

In the following section, the main soil-climatic indicators according to the ESEU system were used individually.

The obtained values in line with the ESEU code are included in Figure 4. 


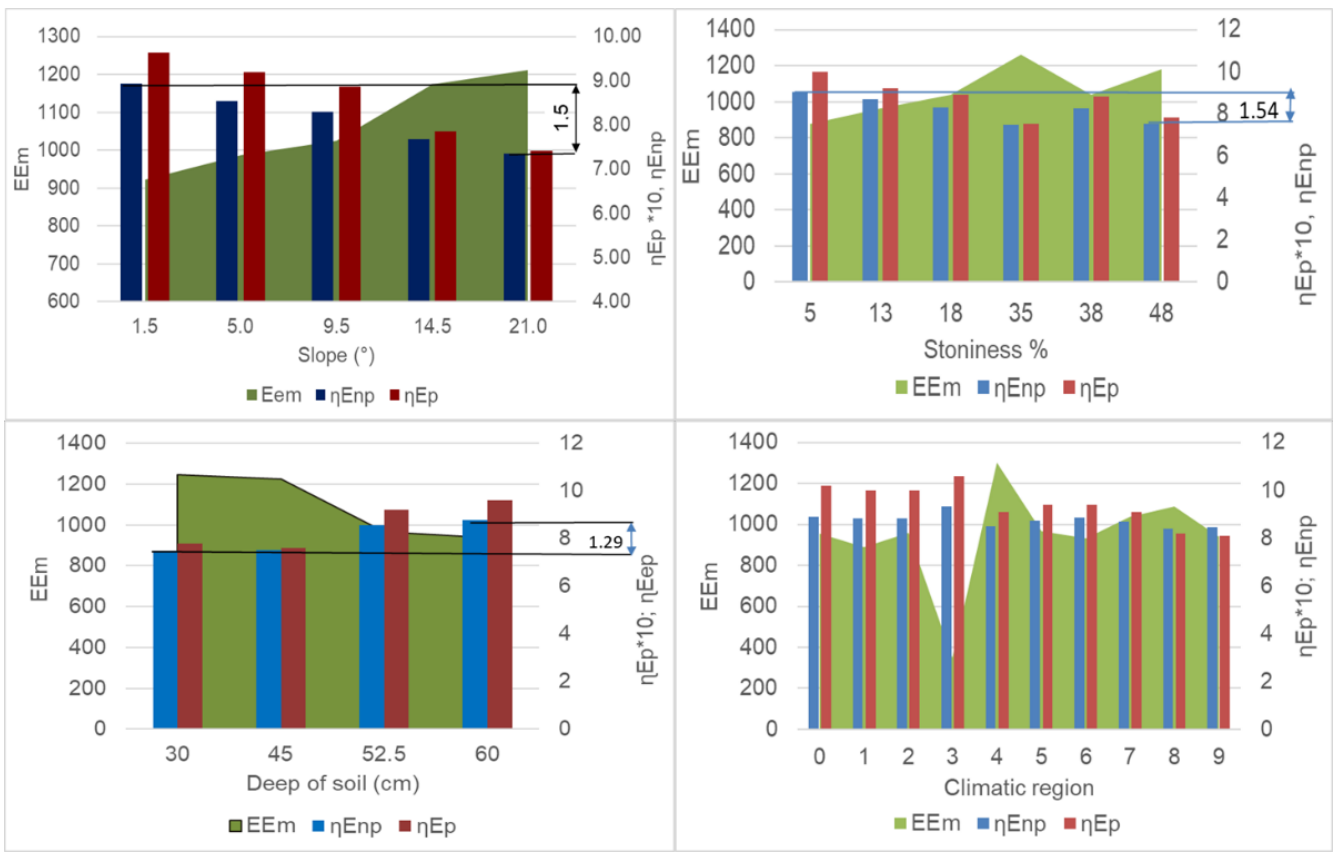

Figure 4. Main configuration and climatic properties and EGMo, GMo and EEm in average of crops.

From the above dependencies, the importance of land and climate configuration indicators is obvious. Due to the slope of soil, the energy efficiency decreases most significantly, namely, by 1.58, while due to the stoniness of soil there is a decrease of 1.54, and due to the depth of soil, of 1.29. Due to the difference in climate regions of 0.94 , the difference in economic efficiency decreases in similar relations, and in absolute values less significantly (values in the graphs are multiplied by 10), but the percentage of the decrease is more pronounced. The percentage changes of all indicators are given in Tables A10-A13.

The results for the main types of soil are shown in Figure 5.

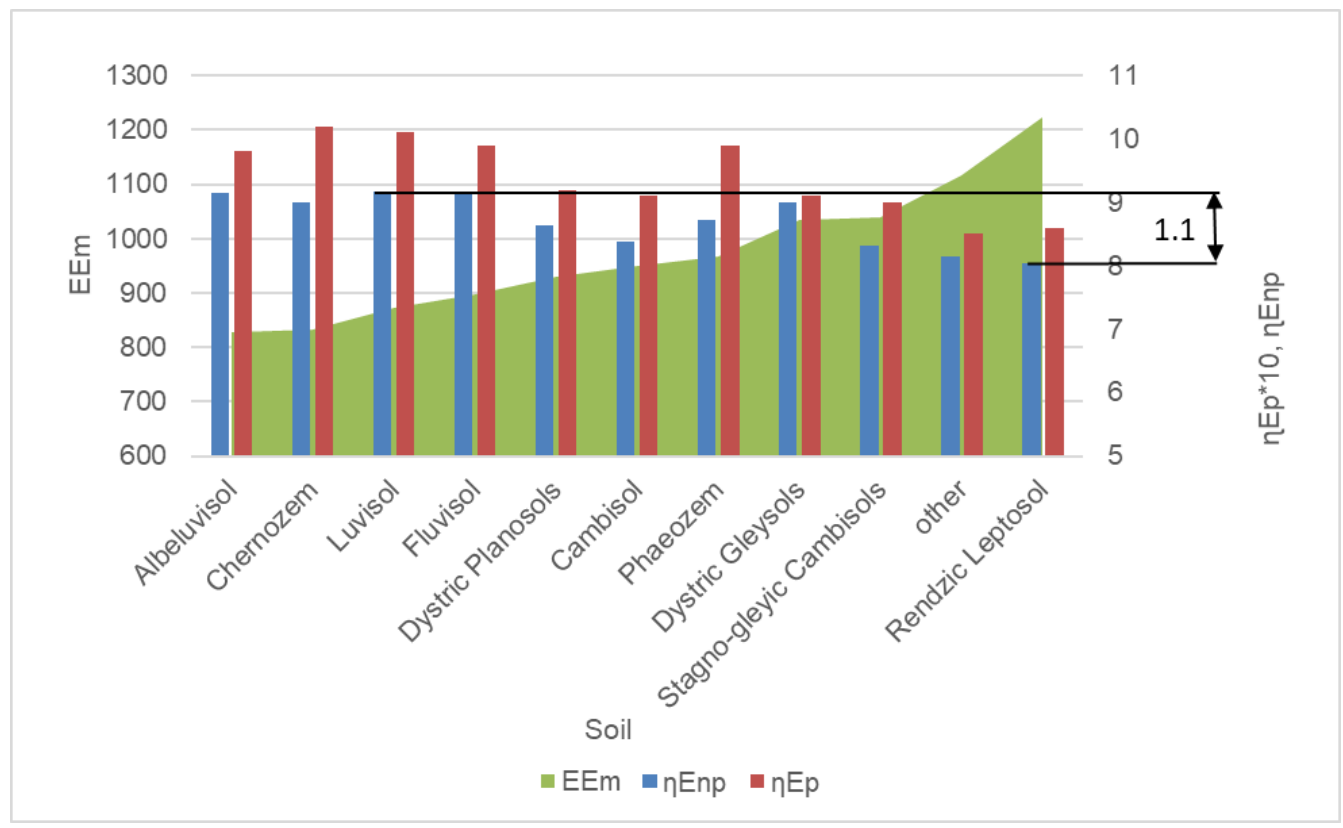

Figure 5. $E E m, \eta E n p$, and $\eta E p$ among the main types of soil in average of crops.

The results show the main difference value of $\eta E n p$ is 1.1; there is also an interesting difference between the energy and economic efficiency in chernozem, which is mainly 
caused by growing economically favorable crops on fertile areas. Higher emissions per energy of outputs correspond to the lower economic and energy efficiency.

\subsection{Assessment of Impacts of Chosen Crops on Penetrometric Resistance}

In order to assess the relationship to soil compaction, a survey was carried out measuring the penetrometer resistance by frequency of crops grown on the plots. The assessment also included cases when more than three values of penetrometer resistance for the respective crop were obtained. The correlation analysis (Table A13) indicates the main dependence of the value of resistance in the monitored crop, determining the effects of penetrometer resistance in the respective soil layers.

The results of the survey of penetrometric resistances from the years 2002-2011 [38] are shown in Figure 6.

\begin{tabular}{|c|c|c|c|c|c|}
\hline Crop & $\begin{array}{c}\text { Crop } \\
\text { repetition } \\
(\mathrm{Nr} .)\end{array}$ & $\begin{array}{l}\text { Penetron } \\
\text { resistance } \\
(\mathrm{MPa}\end{array}$ & $\begin{array}{l}\text { netric } \\
0-18 \mathrm{~cm}\end{array}$ & $\begin{array}{c}\text { Penetrometric } \\
\text { resistance19- } 38 \\
\mathrm{~cm}(\mathrm{MPa})\end{array}$ & $\begin{array}{c}\text { Penetrometric } \\
\text { resistance }>39 \mathrm{~cm} \\
(\mathrm{MPa})\end{array}$ \\
\hline \multirow{4}{*}{ Alfalfa } & 0 & 1.68 & & 4.06 & 4.97 \\
\hline & 1 & 1.63 & & 4.04 & 5.63 \\
\hline & 2 & 1.29 & & 3.06 & 4.58 \\
\hline & 3 & 1.36 & & 3.05 & 4.68 \\
\hline \multirow{4}{*}{$\begin{array}{l}\text { Spring } \\
\text { barley }\end{array}$} & 0 & 1.63 & & 4.11 & 5.18 \\
\hline & 1 & 1.75 & & 4.09 & 4.95 \\
\hline & 2 & 1.63 & & 3.36 & 4.22 \\
\hline & 3 & $\overline{1.40}$ & & 3.38 & 3.90 \\
\hline \multirow{3}{*}{ Poppy } & 0 & 1.72 & & 4.14 & 5.07 \\
\hline & 1 & 1.08 & & 2.58 & 4.06 \\
\hline & 2 & 1.05 & & 2.26 & 3.42 \\
\hline \multirow{3}{*}{$\begin{array}{l}\text { Winter } \\
\text { wheat }\end{array}$} & 0 & 1.78 & & 4.04 & 4.83 \\
\hline & 1 & 1.53 & & 3.97 & 5.15 \\
\hline & 2 & 1.62 & & 3.83 & 4.84 \\
\hline \multirow{6}{*}{$\begin{array}{c}\text { Cereals } \\
\text { (all) }\end{array}$} & 0 & 1.31 & & 3.25 & 3.92 \\
\hline & 1 & 1.53 & & 3.67 & 5.25 \\
\hline & 2 & 1.39 & & 3.66 & 4.69 \\
\hline & 3 & 1.69 & & 4.02 & 4.69 \\
\hline & 4 & 1.90 & & 4.39 & 4.74 \\
\hline & 5 & 1.81 & & 4.67 & 5.85 \\
\hline \multirow{3}{*}{ Triticale } & 0 & 1.63 & & 3.94 & 4.61 \\
\hline & 1 & 1.99 & & 4.61 & 5.20 \\
\hline & 2 & 2.44 & & 5.35 & 5.67 \\
\hline \multirow{4}{*}{$\begin{array}{l}\text { Winter } \\
\text { raps }\end{array}$} & 0 & 1.46 & & 3.52 & 4.35 \\
\hline & 1 & 1.76 & & 4.29 & 4.73 \\
\hline & 2 & 1.93 & & 4.63 & 5.43 \\
\hline & 3 & 4.08 & & 6.58 & 5.76 \\
\hline \multirow{4}{*}{$\begin{array}{l}\text { Silage } \\
\text { maise }\end{array}$} & 0 & 1.65 & & 3.78 & 4.74 \\
\hline & 1 & 1.72 & & 4.44 & 4.64 \\
\hline & 2 & 1.56 & & 4.15 & 4.24 \\
\hline & 3 & 1.85 & & 4.37 & 4.92 \\
\hline
\end{tabular}

Figure 6. The penetrometric resistance according to the number of crop repetitions depending on the depth of the soil.

The results of penetrometer measurements and the identified trends in soil compaction are included in Table A14, with plotted significant dependences of the penetrometric resistance on the crop, the positive effects of alfalfa in subsoil, and the negative impact 
of winter rapeseed growing across the soil profile as well as of maize in the bottom layer at the depth of more than $39 \mathrm{~cm}$. The values in subsoil are crucial for the assessment of effects of penetrometer resistance. The values of penetrometric resistance at the depth of more than $39 \mathrm{~cm}$ can be influenced by penetrometer measurements that ended prematurely due to the solid bedrock. The largest effect on subsoil compaction is seen in poppy seed (difference of $1.88 \mathrm{MPa}$ ) and alfalfa (1.1 MPa). The highest compaction, on the contrary, is reported for winter rapeseed (3.06 $\mathrm{MPa})$ and triticale $(1.4 \mathrm{MPa})$.

\section{Discussion}

The main contribution of this article is a comprehensive view of the economic, energy and emission context of the production of individual crops according to soil and climatic conditions. The evaluation of individual factors is based on the standardized values of inputs and outputs of individual crop processing technologies up to the level of work operations. The work thus enables a systematic view of the production structure of farms in their soil-climatic conditions, and thus enables better planning and management of land use in local conditions. The existing information in the literature is fragmented into partial cases under specific conditions, which are difficult to combine into one framework to find complex contexts. The literature presents analyses of individual energy and economic balance of crops, especially according to higher territorial units and countries, or on the basis of a partial calculation of technology data and simulation of operating conditions [51,52]. This issue is addressed on the basis of data of technological processes individually also according to the yield of straw $[9,53]$ or biomass of selected crops [54]; however, the overall crop balance depending on local conditions for energy, economic and environmental concepts is not addressed. Specific conditions by territorial units are determined on the basis of statistical surveys without functional interdependence [9]. This work does not address the individual technological context of the use of new technological procedures, but the basic standardized framework, by which the newly obtained data can be evaluated. The way in which emission data are processed by ordering ESEUs within individual crops allows the impact of emissions on specific businesses and for specific input choices to be adapted. The way in which emission data are processed by ordering ESEUs within individual crops allows the impact of emissions on specific businesses and for specific input choices to be adapted. Environmental impacts are based on the results of ReCiPe method assessment of specific data for Czech Republic combined with model processes of the LCI database Agri-footprint. A system approach to derive emissions based on this database makes it possible to evaluate individual soil-climatic conditions based on the full impact of technologies. The basis is a complete evaluation of emissions according to primary energy in the manufacture of machinery, according to fuel consumption, fertilizers and protective equipment depending on the doses of material and the performance of kits in individual operations in specific soil and climatic conditions. Emission sources are therefore assessed comprehensively and compared to some other sources, which only evaluate some emission components [55]. The standard LCA database evaluation approach allows for crop-specific evaluation but without the choice of individual emission items according to machine aggregations $[4,56]$. This division makes it possible to adapt the emission factors for the individual difficulty conditions.

A comprehensive evaluation of individual crops shows significant differences between energy and food crops. Higher economic efficiency of food crops is accompanied by increased costs per unit of energy and higher emissions (e.g., soybeans, poppy, sunflower). Higher energy efficiency of feed crops and lower emissions of energy produced can contribute to a further discussion on the focus of food in relation to animal production as well as to discussions on energy production. There are conflicting views on this topic and a detailed LCA analysis of the whole process is needed [57-59]. An important context of the relationship between emissions $E m M J$ from the production of feed crops and grains for human consumption is given in Table 1. 
Table 1. Emissions per GJ of produced energy between crops for food and energy production.

\begin{tabular}{|c|c|c|c|c|c|}
\hline Crops for & Emissions & Unit & Unit/GJ & $\%$ & Dif \% \\
\hline Food & Freshwater ecotoxicity & kg 1.4-DCB & 0.8142 & 100 & \\
\hline Fodder & Freshwater ecotoxicity & $\mathrm{kg}$ 1.4-DCB & 0.4080 & 50.11 & -49.89 \\
\hline Food & Global warming & $\mathrm{kg} \mathrm{CO} 2 \mathrm{eq}$ & 30.1074 & 100 & \\
\hline Fodder & Global warming & $\mathrm{kg} \mathrm{CO} 2 \mathrm{eq}$ & 15.4570 & 51.34 & -48.66 \\
\hline Food & Human carcinogenic toxicity & kg 1.4-DCB & 1.2271 & 100 & \\
\hline Fodder & Human carcinogenic toxicity & kg 1.4-DCB & 0.7158 & 58.34 & -41.66 \\
\hline Food & Terrestrial ecotoxicity & $\mathrm{kg}$ 1.4-DCB & 99.5932 & 100 & \\
\hline Fodder & Terrestrial ecotoxicity & $\mathrm{kg}$ 1.4-DCB & 50.2889 & 50.49 & -49.51 \\
\hline
\end{tabular}

The table shows that emissions produced from energy crops (fodder: clover grass, clover hey, maize silage) are $42-50 \%$ lower per GJ of energy produced than those from food crops (winter wheat, spring barley, peas).

The identified connections between energy, economic and environmental impacts of agricultural crop production show a very significant dependence on soil-climatic conditions. The article separately evaluated the individual properties of land on the operational indicators of crops. The soil depth affects the energy efficiency of crops in the Czech Republic by $15 \%$, the economic efficiency by $21 \%$ and the overall order of emissions by $33 \%$. The land slope affects the energy efficiency of crops in the Czech Republic by $18 \%$, the economic efficiency by $23 \%$ and the overall order of emissions by $31 \%$. The stoniness affects the energy efficiency of crops in the Czech Republic by $14 \%$, the economic efficiency by $18 \%$ and the overall order of emissions by $31 \%$. The results depend on long-term observations of the IAEA and the identification of crop production functions.

Climatic indicators are a factor acting together with soil indicators and according to their specific compositions, overall results can be derived. The interaction is mainly due to the achieved crop yields in specific conditions. From the point of view of the suitability of crops for production, the dependences found show that marginal soils with a shallow soil depth, high stoniness and slope, even on less fertile soils, have higher relative emissions from crop production to $1 \mathrm{MJ}$. Consequently, there is a need to grow crops in these conditions without large emission effects, especially perennial energy crops, which can be used for both animal production and energy production.

The local conditions also cover the effects on the environment in soil based on the mechanical effects of crop growing on soil. The obtained results suggest major impacts of individual crops on soil conditions. The penetrometric resistance of the soil depends mainly on the content of organic matter in the soil and on the method of farming. The content of organic matter in the soil is ensured both by organic fertilization and in deeper layers, above all by the decomposition of the root system of crops. According to the performed penetrometric survey, less compaction of subsoil and subsoil is found in alfalfa and some springs, spring barley and poppy. In terms of lasting effect on improving the condition of the soil in the deeper layers of the soil, alfalfa is very important crop [60-62]. Global biogas (methane) production needs new opportunities for production using legumes on arable land, as they do not significantly degrade soil quality compared to other crops [63], unlike the cultivation of sown maize [64]. Under the new climatic conditions, there is a significant relationship to precipitation, where alfalfa is highly profitable in dry conditions, while clover in humid conditions [65]. A very important advantage is the high production of roots in depth with a positive effect on the soil structure, the content of soil organic matter (SOM) and consequently also on the productivity of the stand [64]. This makes it possible to improve the sustainability and resilience of the natural environment, in particular with regard to reduced external inputs, improved humus balance (carbon, energy and nutrient 
cycle), reduced greenhouse gas emissions and the general positive impact of fodder and catch crops in crop production practices [63].

For the purpose of aligning the growing of crops for food and energy purposes, according to the effects of selected crops on soil ascertained based on the obtained values of penetrometric resistance of individual crops, alfalfa is a highly suitable crop since it improves subsoil compaction and at the same time provides good energy gain. The area under alfalfa, however, substantially decreased in recent years due to the reduction in cattle breeding and has reached its minimum in the Czech Republic. The current need to improve the subsoil conditions together with the need to increase the energy crop capacities, with the concurrent pressure to reduce the cultivation of maize for silage, speaks in favor of its production. Alfalfa can easily be used in all the existing biogas plants, up to a share of $20 \%$, for pellet production and cattle fattening.

The system can analyze 22 environmental indicators in the endpoint category and 18 environmental indicators in the midpoint category [35] and can be combined with the physical effects of crop growing on soil. The physical effects of crop growing on soil constitute an equal impact on the environment as the emissions and assume the form of numerous impacts, especially on soil erosion, soil fertility, resilience to drought as well as water contamination in the case of topsoil wash off. The subsoil compaction keeps increasing as a result of a change in crop composition and climate change, with a decrease in the number of frost days causing soil swelling (frost heaving), as well as an increase in crop yields that have to be harvested and transported from the land by heavy machinery.

\section{Conclusions}

The paper describes the process of developing the system of assessment of soil and climatic impacts on individual crops with respect to economic, energy and environmental indicators for the classified unit of soil and climatic properties-i.e., ESEU in the Czech Republic. The main indicator that was selected to compare the individual conditions was the ratio of the value of individual types of emissions per energy output in MJ. Apart from this indicator, other usual indicators were also set such as the energy of production and economic efficiency of production. The statistical results can also be defined for all the other indicators. Aside from direct classification of soil and climatic conditions, other soil properties, available from the monitoring of the Research Institute for Soil and Water Conservation, were subjected to regression analysis.

With respect to emission impacts, perennial energy crops (silage sorghum, sorrel, hemp), should be encouraged. The current status among major energy crops is of the corn silage with good emission characteristics, but it is necessary to ensure the proper growing conditions with regard to soil quality. The exploration of energy outputs diminishes the nutritional properties of food crops. In spite of this, the analysis shows that in terms of emissions the energy crops bring more benefits when grown under marginal conditions, if the cultivation of these crops under the respective conditions is possible. From the point of view of impact on the soil and sustainable development, justified cultivation of alfalfa with a proven influence on the amelioration of compacted soils is crucial. Alfalfa has increased emission effects compared to clover due to harvesting with a high-power cutter. In the case of alfalfa harvesting on hay, its emissions are comparable to clover. Due to the increasingly difficult search for suitable biomass for energy production while respecting the requirements for food production, alfalfa production is a suitable solution for ensuring the quality of soil and replacement biomass for current energy crops. From the point of view of sustainable development, this solution is very essential for obtaining biomass from agricultural sources. The overall use of results should be based on the evaluation of Pareto optimality [16] in line with the current production options and requirements determined by policies and thorough knowledge of territorial aspects of production. For the sake of further development, the use of maps with the impacts of production on emissions under specific conditions is expected. In the future, it is possible to consider a comprehensive assessment of emission effects in agriculture [66]. 
The article provides a comprehensive view of the joint impact of natural factors on energy, economic and environmental indicators, and thus provides a better picture of their impact on measures for further development of energy in regions and for agricultural policy. As Wohlfart [8] writes, a comprehensive assessment of all contexts is always important for further assessment of a bioeconomy, and therefore also for energy policy. For further development, it is important to compare modeled and measured results in connection with local land conditions for a real evaluation of the conditions of the whole region.

One of the best examples of aligned energy generation and food production is the use of alfalfa as a sanitary crop to address subsoil compaction and as a crop that can help reduce maize silage on the soils at risk of erosion and emissions impact [11,67]. Deeprooting crops are a desirable source of carbon in the deeper layers of the soil, where they also ensure the stability of soil aggregates and sufficient soil permeability. Knowledge of local conditions and their appropriate agricultural use should also become part of the Green for Europe strategy [68], which assumes keeping global warming below $1.5^{\circ} \mathrm{C}$ while still reducing greenhouse gas emissions. The main advantage of energy crops for the low-carbon economy is their potentially lower $\mathrm{CO}_{2}$ production, especially in marginal areas with less soil depth, slope and stoniness. Higher variability of biomass production in the field, taking into account the requirements of sustainable energy, can also lead to higher deregulation and liberalization of the energy market. See [69] for case of ensuring sufficient biomass capacities.

Author Contributions: Conceptualization, V.V. and L.N.; methodology, M.H. and V.V.; software, validation, formal analysis, investigation, data curation, project administration, funding acquisition V.V. All authors have read and agreed to the published version of the manuscript.

Funding: This research was funded by Národní Agentura pro Zemědělský Výzkum, grant no QK1710307.Institutional Review Board: Not applicable.

Informed Consent Statement: Informed consent was obtained from all subjects involved in the study.

Data Availability Statement: Not applicable.

Acknowledgments: The paper was elaborated in the framework of the project of MoA QK1710307 "Economic support for strategic and decision-making processes at national and regional level leading to the optimal use of renewable energy sources, especially biomass, while respecting food selfsufficiency and soil protection". The authors acknowledge the support of the project. The authors also thank Maria Macháčková from the IAEI for preparing the materials for the search, Václav Hofman for help in preparing the data and also all other persons who participated in the validation of the input data used for the preparation of materials for the article including Ivo Pokorný for the MS SQL services.

Conflicts of Interest: The authors declare no conflict of interest. 


\section{Appendix A}

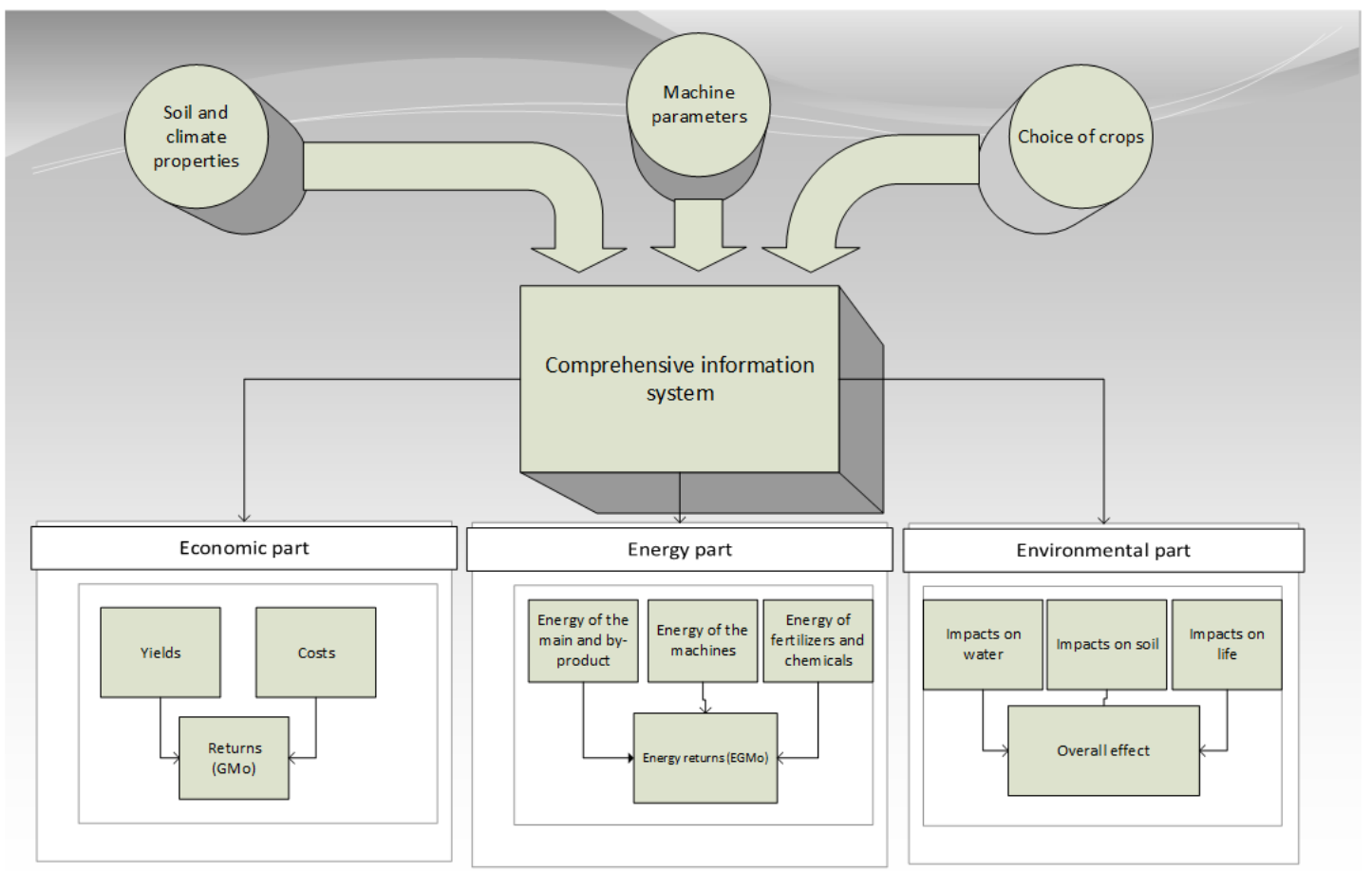

Figure A1. Scheme of the Comprehensive Information System.

\section{Appendix B. Calculation of Costs and Outputs}

Appendix B.1. Costs

The evaluation of costs of parameterized production is based on the sum of costs that have to be spent to achieve the production of crop under ESEU, for plowing technology with operations factored in. The variable costs, VCosts 8, were calculated based on the standardized technological procedures for all main crops according to the Institute of Agricultural Economics and Information.

$$
V \operatorname{Costs}_{i, p, r}=\left(W O_{i, p, r}+T C_{i, p, r}+C M_{i, p, r}+L C_{i, p, r}\right) \times C V C_{i, p}
$$

where: $i$ evaluated soil-climatic unit ESEU; $p$ —evaluated crop; $r$-number of operations; WOi,p, $r=$ unit costs of work operation in line with technologies proposed by Research Institute of Agricultural Engineering, p.r.i., (EUR/ha); TCi,p,r = transport costs (EUR/ha); $C M i, p, r=$ costs of material, fertilizers, plant protection products and auxiliary products $(\mathrm{EUR} / \mathrm{ha}) ; \mathrm{LC}$, p, $r=$ unit labor costs of per cultivation technology and crop under the given soil and climatic conditions based on the five-year average costs (EUR/hour); CVCi,p, $r=$ coefficient of variable costs derived from the IAEI cost survey for ESEU, crop and operation.

The indirect costs of producing of crops are determined with the coefficient ICfc 9 , which is determined according to the IAEI cost survey as a share of indirect ICi,p, $r$ and direct variable crop production costs.

$$
I C f c=I C_{i, p, r} / V \operatorname{Costs}_{i, p, r}
$$

Appendix B.2. Outputs

The price of the parameterized production 10 was determined for standardized yields on ESEU and is composed of the production of the main product and by-product:

$$
P O_{i, p}=Y_{i, p} \times P_{p} C R+Y b_{i, p} \times P b_{p}
$$


where: $Y_{i, p}=$ yield of parameterized production of the main product for the $p$-th crop, which is the corrected normative natural yield of individual main agricultural crops $(p)$ for individual ESEU ( $i$ ) [33] ( $t / h a)$; the yield is updated annually according to the five-year average of crop yields in the IAEA cost survey and the FADN survey; $P p C R=$ normative prices of the main product of individual $p$-th crops differentiated according to climatic regionalization $(E U R / t)$; it is updated annually according to the five-year average of agricultural crop prices from the IAEI and the Czech statistical office (CZSO) survey; $Y_{b}=$ Yield of by-product (straw) on ESEU and crop; $P_{b}=$ a normative price of by-product of crop.

\section{Appendix C}

Table A1. The case of technological operations by soya.

\begin{tabular}{|c|c|c|c|c|c|c|c|c|}
\hline \multicolumn{2}{|c|}{ Operation } & & \multicolumn{2}{|c|}{$\begin{array}{l}\text { 5-Undermining } \\
\text { (Chiseling) } 500 \mathrm{~mm}\end{array}$} & \multirow{2}{*}{\multicolumn{2}{|c|}{$\begin{array}{c}\text { 10-Transport and Spreading } \\
\text { of Limestone (1.5 t/ha to } 2 \\
\text { t/ha)) }\end{array}$}} & \multirow{2}{*}{\multicolumn{2}{|c|}{$\begin{array}{c}\text { 15-Transport and } \\
\text { Spreading of Manure } \\
\text { and Compost (30 t/ha) }\end{array}$}} \\
\hline & & $\begin{array}{r}\text { Number of } \\
\text { Operations } / Y\end{array}$ & & 0.1 & & & & \\
\hline \multirow{2}{*}{ weight } & Tractor & $\mathrm{Kg}$ & & 10,800 & & 6400 & & 7000 \\
\hline & Machine & $\mathrm{Kg}$ & & 2800 & & 6200 & & 9150 \\
\hline \multirow{4}{*}{\multicolumn{2}{|c|}{ Material inputs }} & Name & & & Lime & one, finely ground & & Manure \\
\hline & & Quantity & $\mathrm{MJ} / \mathrm{ha}$ & 0 & & $2 \mathrm{t}$ & & $30 t$ \\
\hline & & Price & EUR/MJ & 0 & & 23.9 & & 11.4 \\
\hline & & Costs & EUR/ha & 0 & & 4.77 & & 68.2 \\
\hline \multirow{5}{*}{\multicolumn{2}{|c|}{$\begin{array}{l}\text { Technical } \\
\text { description of the } \\
\text { operation }\end{array}$}} & Set & $\begin{array}{c}\text { TK } \\
200 \mathrm{~kW}\end{array}$ & $\begin{array}{l}\text { Chisel } \\
\text { bar } 3 \mathrm{~m}\end{array}$ & $\begin{array}{c}\text { TK } \\
120 \mathrm{~kW}\end{array}$ & $\begin{array}{l}\text { Spread it out. } \\
\text { semitrailer } \\
12,000 \mathrm{~L}\end{array}$ & $\begin{array}{c}\text { TK } \\
130 \mathrm{~kW}\end{array}$ & $\begin{array}{l}\text { Manure } \\
\text { spreader } \\
16 \mathrm{t}\end{array}$ \\
\hline & & \multirow{3}{*}{ Normatives } & $\mathrm{h} / \mathrm{ha}$ & 0.56 & & 0.5 & & 1.33 \\
\hline & & & 1/ha & 21 & & 5.5 & & 25 \\
\hline & & & EUR/ha & 49.3 & & 22.3 & & 106.2 \\
\hline & & Costs & EUR/ha & 4.93 & & 2.22 & & 21.2 \\
\hline \multicolumn{3}{|c|}{$\begin{array}{c}\text { Variable costs total } \\
\text { EUR/ha }\end{array}$} & & 4.93 & & 7 & & 89.4 \\
\hline
\end{tabular}

Source: Research Institute of Agricultural Engineering, p.r.i., 2018.

Table A2. Description of the climatic regions.

\begin{tabular}{cccccc}
\hline $\begin{array}{c}\text { Region Numeric } \\
\text { Code }\end{array}$ & $\begin{array}{c}\text { Temperature Sum } \\
{ }^{\circ} \text { C/Year }\end{array}$ & $\begin{array}{c}\text { Temperature } \\
\text { Average }{ }^{\circ} \text { C/Year }\end{array}$ & $\begin{array}{c}\text { Rainfall Average } \\
\text { mm/Year }\end{array}$ & $\begin{array}{c}\text { Risk of Dry Years } \\
\text { Coefficient }\end{array}$ & $\begin{array}{c}\text { Moisture Security } \\
\mathbf{1} \text { Minimum, } \\
\mathbf{1 0} \text { Maximum }\end{array}$ \\
\hline 0 & 3680 & 10.08 & 550 & 0.40 & 1.5 \\
\hline 1 & 3430 & 9.40 & 450 & 0.50 & 3 \\
\hline 2 & 3430 & 9.40 & 550 & 0.25 & 0.15 \\
\hline 3 & 3380 & 9.26 & 600 & 0.35 & 2 \\
\hline 4 & 3230 & 8.85 & 500 & 0.23 & 7 \\
\hline 5 & 3080 & 8.44 & 600 & 0.05 & 10 \\
\hline 6 & 3330 & 9.12 & 800 & 0.10 & 10 \\
\hline 7 & 3030 & 8.30 & 700 & 0.03 & 10 \\
\hline 8 & 2830 & 7.75 & 750 & 0.00 & 10 \\
\hline 9 & 2680 & 7.34 & 850 & & 10 \\
\hline
\end{tabular}


Table A3. Energy of crop production.

\begin{tabular}{|c|c|c|c|c|}
\hline Crop & Product & $\begin{array}{c}\text { Dry Matter Main } \\
\text { Product } \%\end{array}$ & $\begin{array}{c}\text { Energy of Main } \\
\text { Production (MJ/kg of } \\
\text { Product) }\end{array}$ & $\begin{array}{c}\text { By-Product } \\
\text { Energy (MJ/kg } \\
\text { of Product) }\end{array}$ \\
\hline Potatoes & potatoes & 22 & 3.45 & 3 \\
\hline Early potatoes & potatoes & 22 & 3.45 & 3 \\
\hline Seedling potatoes & potatoes & 22 & 3.45 & 3 \\
\hline Sugar beet & bulbs & 23 & 3.89 & 1.76 \\
\hline Barley spring & grain & 85 & 15.93 & 13.73 \\
\hline Barley spring malt & grain & 85 & 15.93 & 13.73 \\
\hline Winter barley & grain & 85 & 15.48 & 13.73 \\
\hline Clover on green & green matter & 21 & 3.07 & \\
\hline Clover on hay & hay & 85 & 13.06 & \\
\hline Clover grass & hay & 85 & 13.13 & \\
\hline Corn for silage & corn silage $32 \%$ of moisture & 32 & 5.984 & \\
\hline Corn on the cob & grain & 85 & 16.21 & 13.5 \\
\hline Grass & hay & 85 & 13.19 & \\
\hline Poppy & grain & 85 & 15.48 & 13.69 \\
\hline Oat & grain & 85 & 17.45 & 13.38 \\
\hline Nonfood wheat & grain & 85 & 15.82 & 13.46 \\
\hline Food wheat & grain & 85 & 15.82 & 13.46 \\
\hline Winter rape & grain & 85 & 25.22 & 13.64 \\
\hline Triticale & grain & 85 & 16.22 & 13.46 \\
\hline Alfalfa & silage $40 \%$ & 40 & 6.25 & \\
\hline Rye & grain & 85 & 15.48 & 13.46 \\
\hline Mustard & green matter & 21 & 2.67 & \\
\hline Pea & grain & 85 & 14.15 & 13.63 \\
\hline Hemp & dry matter & 85 & 13.69 & \\
\hline Buckwheat mixture bundles & green matter & 21 & 3.07 & \\
\hline Soya & grain & 85 & 17.66 & 13.63 \\
\hline Sunflower & grain & 85 & 12.41 & \\
\hline Bundle & green matter & 21 & 3.07 & \\
\hline Sorghum & green matter & 21 & 3.07 & \\
\hline Sorrel & dry matter & 85 & 19.17 & \\
\hline
\end{tabular}

Source: Preininger [22].

Table A4. Used unit costs of materials.

\begin{tabular}{ccc}
\hline Inputs & Unit Price (EUR/Unit) & Unit \\
\hline Oil & 0.98 & EUR/L \\
\hline Work & 9.09 & EUR/hod \\
\hline $\mathrm{N}$ & 1.55 & $\mathrm{EUR} / \mathrm{Kg}$ \\
\hline $\mathrm{P} 2 \mathrm{O} 5$ & 2.05 & $\mathrm{EUR} / \mathrm{Kg}$ \\
\hline $\mathrm{K} 2 \mathrm{O}$ & 1.09 & $\mathrm{EUR} / \mathrm{Kg}$ \\
\hline $\mathrm{MgO}$ & 1.68 & $\mathrm{EUR} / \mathrm{Kg}$ \\
\hline $\mathrm{CaO}$ & 0.36 & $\mathrm{EUR} / \mathrm{Kg}$ \\
\hline Sulfur & 0.48 & $\mathrm{EUR} / \mathrm{Kg}$ \\
\hline Chemicals & 89.73 & $\mathrm{EUR} / \mathrm{Kg}$ \\
\hline Manure & 40.36 & $\mathrm{EUR} / \mathrm{t}$ \\
\hline
\end{tabular}


Table A5. Conversion factors for calculating the energy contained in machines.

\begin{tabular}{ccc}
\hline Machine Category & Value & Unit \\
\hline Tractors & 95.7 & $\mathrm{MJ} / \mathrm{kg}$ \\
\hline Tillage machines & 99.2 & $\mathrm{MJ} / \mathrm{kg}$ \\
\hline Seeders & 95.4 & $\mathrm{MJ} / \mathrm{kg}$ \\
\hline Spreaders and sprayers & 95.4 & $\mathrm{MJ} / \mathrm{kg}$ \\
\hline Combine harvester & 83.5 & $\mathrm{MJ} / \mathrm{kg}$ \\
\hline Straw harvest & 95.4 & $\mathrm{MJ} / \mathrm{kg}$ \\
\hline Traffic machine & 83.5 & $\mathrm{MJ} / \mathrm{kg}$ \\
\hline Source: Preininger [22] & &
\end{tabular}

Source: Preininger [22].

Table A6. Energy of used materials.

\begin{tabular}{|c|c|c|}
\hline Inputs & Value (MJ/Unit) & Unit \\
\hline oil & 40.7 & $\mathrm{dm}^{3} \mathrm{dm}^{3}$ \\
\hline benzine & 41.5 & $\mathrm{dm}^{3} \mathrm{dm}^{3}$ \\
\hline propane butane & 50.8 & $\mathrm{~kg}$ \\
\hline natural gas & 33.8 & $\mathrm{~m}^{3}$ \\
\hline lubricants & 45.2 & $\mathrm{dm}^{3} \mathrm{dm}^{3}$ \\
\hline electrical energy & 9.6 & $\mathrm{kWh}$ \\
\hline coal & 27.8 & $\mathrm{~kg}$ \\
\hline cereal seed & 8 & $\mathrm{~kg}$ of seeds \\
\hline oilseeds, rape, flax & 5.7 & $\mathrm{~kg}$ of seeds \\
\hline seed potatoes & 2 & $\mathrm{~kg}$ of seed \\
\hline beet seed (batch of 100,000 seeds) & 172 & dose \\
\hline corn seed $(50,000$ seeds $)$ & 16.2 & dose \\
\hline pea seed bean & 7 & $\mathrm{~kg}$ of seeds \\
\hline $\mathrm{N}$ & 82.5 & $\mathrm{~kg}$ \\
\hline $\mathrm{P}_{2} \mathrm{O}_{5}$ & 17.7 & $\mathrm{~kg}$ \\
\hline $\mathrm{K}_{2} \mathrm{O}$ & 9.6 & $\mathrm{~kg}$ \\
\hline
\end{tabular}

Source: Preininger [22].

Table A7. Price and energy of nutrients in cow manure.

\begin{tabular}{|c|c|c|c|c|}
\hline Nutrients & Nutrients $\mathrm{kg} / \mathrm{t}^{2}$ & Price EUR/kg ${ }^{1}$ & Price Total EUR/t ${ }^{1}$ & Energy $\mathrm{MJ} / \mathrm{t}^{3}$ \\
\hline $\mathrm{N}$ & 5 & 1.55 & 7.73 & \\
\hline $\mathrm{P}_{2} \mathrm{O}_{2}$ & 3.1 & 2.05 & 6.34 & \\
\hline $\mathrm{K}_{2} \mathrm{O}$ & 7.1 & 1.09 & 7.75 & \\
\hline $\mathrm{Mg}$ & 1.5 & 1.68 & 2.52 & \\
\hline $\mathrm{Ca}$ & 4.5 & 0.36 & 1.62 & \\
\hline \multirow[t]{2}{*}{$S$} & 1 & 0.48 & 0.48 & \\
\hline & Total & & 26.43 & 463 \\
\hline
\end{tabular}


Table A8. Average emissions global warming and efficiency of crops.

\begin{tabular}{ccccc}
\hline Crop & Emission & $\eta \boldsymbol{E n}$ & $\eta \boldsymbol{E} \times \mathbf{1 0}$ & kg C02/GJ \\
\hline Forage sorrel & global warming & 29.24 & 5.53 & 2.96 \\
\hline Clover meadow on hay & global warming & 11.97 & 9.59 & 7.58 \\
\hline Sugar beet & global warming & 11.62 & 12.12 & 8.51 \\
\hline Maize silage & global warming & 8.62 & 7.46 & 11.42 \\
\hline Oat & global warming & 7.36 & 11.95 & 12.84 \\
\hline Maize on the corn & global warming & 8.63 & 11.60 & 13.19 \\
\hline Hemp sown & global warming & 9.25 & 4.27 & 14.70 \\
\hline Spring barley & global warming & 5.94 & 9.64 & 16.41 \\
\hline Winter rye & global warming & 6.49 & 10.10 & 17.93 \\
\hline Triticale & global warming & 6.05 & 9.05 & 19.45 \\
\hline Winter barley & global warming & 5.64 & 7.90 & 20.17 \\
\hline Winter wheat & global warming & 5.64 & 8.86 & 20.76 \\
\hline Winter rape & global warming & 5.78 & 9.65 & 28.53 \\
\hline Sorghum for silage & global warming & 26.53 & 6.88 & 30.01 \\
\hline Alfalfa & global warming & 4.37 & 4.53 & 34.45 \\
\hline Ware potatoes & global warming & 2.29 & 13.24 & 36.86 \\
\hline Peas & global warming & 4.01 & 7.01 & 44.19 \\
\hline Poppy seeds & global warming & 2.50 & 11.89 & 44.80 \\
\hline Soya & global warming & 4.45 & 10.15 & 51.88 \\
\hline Sunflower & global warming & 0.93 & 8.49 & 59.34 \\
\hline & & & & \\
\hline
\end{tabular}

Table A9. Average emissions of terrestrial ecotoxicity and efficiency of crops.

\begin{tabular}{|c|c|c|c|c|}
\hline Crop & Emission & $\eta E n$ & $\eta E \times 10$ & kg 1,4-DCB/GJ \\
\hline Forage sorrel & Terrestrial ecotoxicity & 29.241 & 5.533 & 9.510 \\
\hline Clover meadow on hay & Terrestrial ecotoxicity & 11.971 & 9.593 & 24.442 \\
\hline Sugar beet & Terrestrial ecotoxicity & 11.624 & 12.122 & 27.214 \\
\hline Maize silage & Terrestrial ecotoxicity & 8.620 & 7.460 & 36.668 \\
\hline Oat & Terrestrial ecotoxicity & 7.363 & 11.952 & 43.309 \\
\hline Maize on the corn & Terrestrial ecotoxicity & 8.628 & 11.596 & 43.632 \\
\hline Hemp sown & Terrestrial ecotoxicity & 9.249 & 4.271 & 47.801 \\
\hline Spring barley & Terrestrial ecotoxicity & 5.945 & 9.639 & 54.442 \\
\hline winter rye & Terrestrial ecotoxicity & 6.489 & 10.096 & 60.899 \\
\hline Triticale & Terrestrial ecotoxicity & 6.045 & 9.050 & 65.772 \\
\hline Winter barley & Terrestrial ecotoxicity & 5.639 & 7.899 & 67.811 \\
\hline Winter wheat & Terrestrial ecotoxicity & 5.636 & 8.864 & 70.070 \\
\hline Winter rape & Terrestrial ecotoxicity & 5.775 & 9.655 & 97.490 \\
\hline Sorghum for silage & Terrestrial ecotoxicity & 26.525 & 6.879 & 98.681 \\
\hline Alfalfa & Terrestrial ecotoxicity & 4.366 & 4.532 & 112.083 \\
\hline Ware potatoes & Terrestrial ecotoxicity & 2.289 & 13.236 & 117.159 \\
\hline Peas & Terrestrial ecotoxicity & 4.010 & 7.011 & 143.674 \\
\hline Poppy seeds & Terrestrial ecotoxicity & 2.503 & 11.895 & 153.232 \\
\hline Soya & Terrestrial ecotoxicity & 4.454 & 10.146 & 166.673 \\
\hline Sunflower & Terrestrial ecotoxicity & 0.932 & 8.490 & 197.321 \\
\hline
\end{tabular}


Table A10. Average emissions and efficiency of crops according to the climatic regions.

\begin{tabular}{ccccccc}
\hline \multirow{2}{*}{ CR } & \multicolumn{2}{c}{$\eta E n p$} & \multicolumn{2}{c}{$\eta E p$} & \multicolumn{2}{c}{ EEm } \\
\cline { 2 - 7 } & Value & \% & Value & $\%$ & Value & \% \\
\hline 0 & 8.88 & 95.18 & 10.2 & 96.23 & 954 & 272.36 \\
\hline 1 & 8.81 & 94.43 & 10 & 94.34 & 891 & 254.53 \\
\hline 2 & 8.81 & 94.43 & 10 & 94.34 & 959 & 273.78 \\
\hline 3 & 9.33 & 100.00 & 10.6 & 100.00 & 350 & 100.00 \\
\hline 4 & 8.49 & 91.00 & 9.1 & 85.85 & 1301 & 371.52 \\
\hline 5 & 8.72 & 93.46 & 9.4 & 88.68 & 966 & 275.75 \\
\hline 6 & 8.86 & 94.96 & 9.4 & 88.68 & 933 & 266.46 \\
\hline 7 & 8.7 & 93.25 & 9.1 & 85.85 & 1036 & 295.91 \\
\hline 8 & 8.39 & 89.92 & 8.2 & 77.36 & 1087 & 310.49 \\
\hline 9 & 8.45 & 90.57 & 8.1 & 76.42 & 941 & 268.69 \\
\hline $\min$ & 8.39 & 89.92 & 8.1 & 76.42 & 350 & 100.00 \\
\hline $\max$ & 9.33 & 100.00 & 10.6 & 100.00 & 1301 & 371.52 \\
\hline
\end{tabular}

Table A11. Average emissions and efficiency of crops according to the slope.

\begin{tabular}{ccccccc}
\hline \multirow{2}{*}{ Slope $\left({ }^{\circ}\right)$} & \multicolumn{2}{c}{$\eta E n p$} & \multicolumn{2}{c}{$\eta E p$} & \multicolumn{2}{c}{ EEm } \\
\cline { 2 - 7 } & Value & $\%$ & Value & $\%$ & Value & $\%$ \\
\hline 1.5 & 8.93 & 100.00 & 9.63 & 100.00 & 922.04 & 100.00 \\
\hline 5.0 & 8.54 & 95.68 & 9.20 & 95.53 & 987.03 & 107.05 \\
\hline 9.5 & 8.29 & 92.86 & 8.87 & 92.12 & 1025.44 & 111.21 \\
\hline 14.5 & 7.68 & 86.04 & 7.85 & 81.52 & 1174.31 & 127.36 \\
\hline 21.0 & 7.35 & 82.31 & 7.42 & 77.03 & 1211.89 & 131.44 \\
\hline $\min$ & 7.35 & 82.31 & 7.42 & 77.03 & 922.04 & 100.00 \\
\hline $\max$ & 8.93 & 100.00 & 9.63 & 100.00 & 1211.89 & 131.44 \\
\hline
\end{tabular}

Table A12. Average emissions and efficiency of crops according to the depth of the soil.

\begin{tabular}{ccccccc}
\hline \multirow{2}{*}{$\begin{array}{c}\text { Depth of } \\
\text { Soil }(\mathbf{c m})\end{array}$} & \multicolumn{2}{c}{$\eta E n p$} & \multicolumn{2}{c}{$\eta E p$} & \multicolumn{2}{c}{ EEm } \\
\cline { 2 - 7 } & Value & $\%$ & Value & $\%$ & Value & $\%$ \\
\hline 30 & 7.5 & 85.32 & 7.8 & 81.25 & 1246.73 & 132.765 \\
\hline 45 & 7.53 & 85.67 & 7.6 & 79.17 & 1223.34 & 130.2742 \\
\hline 52.5 & 8.57 & 97.50 & 9.2 & 95.83 & 968.6 & 103.1468 \\
\hline 60 & 8.79 & 100.00 & 9.6 & 100.00 & 939.05 & 100 \\
\hline $\min$ & 7.50 & 85.32 & 7.60 & 79.17 & 939.05 & 100 \\
\hline $\max$ & 8.79 & 100.00 & 9.60 & 100.00 & 1246.73 & 132.765 \\
\hline
\end{tabular}


Table A13. Average emissions and efficiency of crops according to the stoniness.

\begin{tabular}{ccccccc}
\hline \multirow{2}{*}{ Stoniness } & \multicolumn{2}{c}{$\eta$ Enp } & \multicolumn{2}{c}{$\eta E p$} & \multicolumn{2}{c}{ EEm } \\
\cline { 2 - 7 } & Value & $\%$ & Value & $\%$ & Value & $\%$ \\
\hline 5 & 9.04 & 104.27 & 10 & 108.70 & 874.42 & 90.68 \\
\hline 12.5 & 8.67 & 100.00 & 9.2 & 100.00 & 964.27 & 100.00 \\
\hline 17.5 & 8.29 & 95.62 & 8.9 & 96.74 & 1040.84 & 107.94 \\
\hline 35 & 7.46 & 86.04 & 7.5 & 81.52 & 1260.94 & 130.77 \\
\hline 37.5 & 8.24 & 95.04 & 8.8 & 95.65 & 1036.69 & 107.51 \\
\hline 47.5 & 7.5 & 86.51 & 7.8 & 84.78 & 1181.26 & 122.50 \\
\hline $\min$ & 7.46 & 86.04 & 7.50 & 81.52 & 964.27 & 100.00 \\
\hline $\max$ & 8.67 & 100.00 & 9.20 & 100.00 & 1260.94 & 130.77 \\
\hline
\end{tabular}

Table A14. Correlation analysis of penetrometric resistance according to the frequency of crops on the plot.

\begin{tabular}{|c|c|c|c|c|c|c|c|c|c|}
\hline & & Alfalfa & $\begin{array}{l}\text { Spring } \\
\text { Barley }\end{array}$ & Poppy & Cereals & Triticale & $\begin{array}{l}\text { Raps } \\
\text { Winter }\end{array}$ & $\begin{array}{l}\text { Maize } \\
\text { Silage }\end{array}$ & $\begin{array}{l}\text { Winter } \\
\text { Wheat }\end{array}$ \\
\hline \multirow{3}{*}{$\begin{array}{l}\text { Penetrometric } \\
\text { resistance } 0-18 \mathrm{~cm}\end{array}$} & Pearson Correlation & -0.076 & 0.006 & $-0.159 * *$ & $0.172 * *$ & 0.078 & $0.202 * *$ & 0.006 & 0.023 \\
\hline & Sig. (2-tailed) & 0.185 & 0.917 & 0.005 & 0.003 & 0.175 & 0.000 & 0.919 & 0.688 \\
\hline & $\mathrm{N}$ & 306 & 306 & 306 & 306 & 306 & 306 & 306 & 306 \\
\hline \multirow{3}{*}{$\begin{array}{l}\text { Penetrometric } \\
\text { resistance 19-38 cm }\end{array}$} & Pearson Correlation & -0.118 * & -0.106 & $-0.215^{* *}$ & $0.164 * *$ & 0.077 & $0.236^{* *}$ & 0.095 & 0.023 \\
\hline & Sig. (2-tailed) & 0.038 & 0.065 & 0.000 & 0.004 & 0.178 & 0.000 & 0.097 & 0.683 \\
\hline & $\mathrm{N}$ & 306 & 306 & 306 & 306 & 306 & 306 & 306 & 306 \\
\hline \multirow{3}{*}{$\begin{array}{l}\text { Penetrometric } \\
\text { resistance }>39 \mathrm{~cm}\end{array}$} & Pearson Correlation & -0.044 & $-0.225^{* *}$ & $-0.219^{* *}$ & 0.083 & $0.134^{*}$ & $0.176^{* *}$ & $0.247^{* *}$ & -0.003 \\
\hline & Sig. (2-tailed) & 0.476 & 0.000 & 0.000 & 0.179 & 0.029 & 0.004 & 0.000 & 0.958 \\
\hline & $\mathrm{N}$ & 264 & 264 & 264 & 264 & 264 & 264 & 264 & 264 \\
\hline
\end{tabular}

${ }^{* *}$ Correlation is significant at the 0.01 level (2-tailed). ${ }^{*}$ Correlation is significant at the 0.05 level (2-tailed).

\section{References}

1. Monforti-Ferrario, F.; Dallemand, J.-F.; Pascua, I.P.; Motola, V.; Banja, M.; Scarlat, N.; Medarac, H.; Castellazzi, L.; Labanca, N.; Bertoldi, P.; et al. Energy Use in the EU Food Sector: State of Play and Opportunities for Improvement; Publications Office of the European Union: Luxembourg, 2015. [CrossRef]

2. Mcmichael, A.J.; Powles, J.W.; Butler, C.D.; Uauy, R. Series Energy and Health 5 Food, livestock production, energy, climate change, and health. Lancet 2007, 370, 1253-1263. [CrossRef]

3. Máté, D.; Rabbi, M.F.; Novotny, A.; Kovács, S. Grand challenges in Central Europe: The relationship of food security, climate change, and energy use. Energies 2020, 13, 5422. [CrossRef]

4. Colantoni, A.; Picchio, R.; Marucci, A.; Di Mattia, E.; Cristofori, V.; Recanatesi, F.; Villarini, M.; Monarca, D.; Cecchini, M. WP3-Innovation in Agriculture and Forestry Sector for Energetic Sustainability. Energies 2020, 13, 5985. [CrossRef]

5. Maggio, A.; Van, T.; Jean, C.; Malingreau, P. JRC Science and Policy Reports-Global Food Security 2030—Assessing trends with a View to Guiding Future EU Policies; Publications Office of the European Union: Luxembourg, 2015. [CrossRef]

6. Nicholson, C.F.; Stephens, E.C.; Kopainsky, B.; Thornton, P.K.; Jones, A.D.; Parsons, D.; Garrett, J. Food security outcomes in agricultural systems models: Case examples and priority information needs. Agric. Syst. 2021, 188, 103030. [CrossRef]

7. Al Blooshi, L.S.; Ksiksi, T.S.; Aboelenein, M.; Gargoum, A.S. The impact of climate change on agricultural and livestock production and groundwater characteristics in Abu Dhabi, UAE. Nat. Environ. Pollut. Technol. 2020, 19, 1945-1956. [CrossRef]

8. Wohlfahrt, J.; Ferchaud, F.; Gabrielle, B.; Godard, C.; Kurek, B.; Loyce, C.; Therond, O. Characteristics of bioeconomy systems and sustainability issues at the territorial scale. A review. J. Clean. Prod. 2019, 232, 898-909. [CrossRef]

9. Gradziuk, P.; Gradziuk, B.; Trocewicz, A.; Jendrzejewski, B. Potential of straw for energy purposes in Poland-Forecasts based on trend and causal models. Energies 2020, 13, 5054. [CrossRef]

10. Arthurson, V. Closing the global energy and nutrient cycles through application of biogas residue to agricultural land-Potential benefits and drawbacks. Energies 2009, 2, 226-242. [CrossRef]

11. Mann, L.; Tolbert, V.; Cushman, J. Potential environmental effects of corn (Zea mays L.) stover removal with emphasis on soil organic matter and erosion. Agric. Ecosyst. Environ. 2002, 89, 149-166. [CrossRef] 
12. Hettenhaus, J. Achieving sustainable production of agricultural biomass for biorefinery feedstock. Ind. Biotechnol. 2006, 2, 257-274. [CrossRef]

13. Panoutsou, C.; Alexopoulou, E. Costs and profitability of crops for bioeconomy in the EU. Energies 2020, 13, 1222. [CrossRef]

14. Gaydon, D.S.; Balwinder-Singh; Wang, E.; Poulton, P.L.; Ahmad, B.; Ahmed, F.; Akhter, S.; Ali, I.; Amarasingha, R.; Chaki, A.K.; et al. Evaluation of the APSIM model in cropping systems of Asia. Field Crops Res. 2017, 204, 52-75. [CrossRef]

15. Hercher-Pasteur, J.; Loiseau, E.; Sinfort, C.; Hélias, A. Energetic assessment of the agricultural production system. A review. Agron. Sustain. Dev. 2020, 40, 1-23. [CrossRef]

16. Razm, S.; Nickel, S.; Sahebi, H. A multi-objective mathematical model to redesign of global sustainable bioenergy supply network. Comput. Chem. Eng. 2019, 128,1-20. [CrossRef]

17. Bentsen, N.S.; Larsen, S.; Stupak, I. Sustainability governance of the Danish bioeconomy—The case of bioenergy and biomaterials from agriculture. Energy. Sustain. Soc. 2019, 9, 40. [CrossRef]

18. Ministry of Industry and Trade of the Czech Republic. The Czech Republic 's National Energy and Climate Plan (Vnitrostátní Plán České Republiky v Oblasti Energetiky a Klimatu); MPO: Prague, Czech Republic, 2020.

19. Fluck, R.C. Energy in Farm Production; Elsevier: Amsterdam, The Netherlands, 2001.

20. Slesser, M.; Wallace, F. Energy Consumption per Tonne of Competing Agricultural Products Available to the EC; Office for Official Publications of the European Communities, Wisconsin Unioversity: Madison, WI, USA, 1982; p. 82.

21. Patterson, M.G. What is energy efficiency?: Concepts, indicators and methodological issues. Energy Policy 1996, 24, 377-390 [CrossRef]

22. Preininger, M. Energetic Evaluation of Production Process in Crop Production (Energetické Hodnocení Výrobních Procesů v Rostlinné Výrobě). Praha: Ústav vědeckotechnických Informací pro Zemědělství. 1987. Available online: https:/ / www.cistbrno. cz/Record/mzk.MZK01-000535029/UserComments\#tabnav (accessed on 3 March 2021).

23. Voltr, V. Description on ESEU. Available online: https:/ /www.uzei.cz/data/usr_001_cz_soubory/210210_Description_of_ESEU. pdf (accessed on 18 February 2021).

24. $227 / 2018 \mathrm{Sb}$. Decree on the Characteristics of Rated Soil Ecological Units and the Procedure for Their Management and Updating (Vyhláška o Charakteristice Bonitovaných Půdně Ekologických Jednotek a Postupu Pro Jejich Vedení a Aktualizaci). Available online: https: / / www.zakonyprolidi.cz/cs/2018-227 (accessed on 18 February 2021).

25. Voltr, V. Characteristic of the Main Soil Units. Available online: https://www.uzei.cz/data/usr_001_cz_soubory/210218 _characteristic_of_the_Main_Soil_Units.pdf (accessed on 18 February 2021).

26. Voltr, V. Concept of soil fertility and soil productivity: Evaluation of agricultural sites in the Czech Republic. Arch. Agron. Soil Sci. 2012, 58. [CrossRef]

27. Brandão, M.; Clift, R.; Milà, L.C.; Basson, L. A life-cycle approach to characterising environmental and economic impacts of multifunctional land-use systems: An integrated assessment in the UK. Sustainability 2010, 2, 3747-3776. [CrossRef]

28. Baum, R.; Bieńkowski, J. Eco-efficiency in measuring the sustainable production of agricultural crops. Sustainability 2020, $12,1418$. [CrossRef]

29. Vatsanidou, A.; Kavalaris, C.; Fountas, S.; Katsoulas, N.; Gemtos, T. A life cycle assessment of biomass production from energy crops in crop rotation using different tillage system. Sustainability 2020, 12, 6978. [CrossRef]

30. Kiesel, A.; Wagner, M.; Lewandowski, I. Environmental performance of miscanthus, switchgrass and maize: Can C4 perennials increase the sustainability of biogas production? Sustainability 2017, 9, 5. [CrossRef]

31. Al-Mansour, F.; Jejcic, V. A model calculation of the carbon footprint of agricultural products: The case of Slovenia. Energy 2017, 136, 7-15. [CrossRef]

32. Durlinger, B.; Consultants, B.; Koukouna, E.; Broekema, R.; Van Paassen, M.; Scholten, J. Agri-Footprint 4.0; Agri Footprint: Gouda, The Netherlands, 2017.

33. Voltr, V. Economy of Crops on ESEU. Available online: https://www.uzei.cz/data/usr_001_cz_soubory/210210_Economy_of_ crops_on_ESEU.pdf (accessed on 18 February 2021).

34. Voltr, V. Fertilizers on ESEU and Crop. Available online: https://www.uzei.cz/data/usr_001_cz_soubory/210218_Fertilizers_ on_ESEU.pdf (accessed on 18 February 2021).

35. Voltr, V. Ecologic Indicators on ESEU. Available online: https://www.uzei.cz/data/usr_001_cz_soubory/midp_ind_En.pdf (accessed on 18 February 2021).

36. Voltr, V.; Hruška, M.; Nobilis, L.; Fuksa, P. Methodology for Economic, Energy and Environmental Assessment of Crop Production. (Metodika Ekonomického, Energetického a Environmentálního Hodnocení Výroby Plodin); ÚZEI: Prague, Czech Republic, 2019; ISBN 97880-7271-242-7.

37. Voltr, V.; Hruška, M.; Šařec, P.; Leština, J.; Froněk, P. The Methodology for the Valuated Soil-é Soil-Ecological units (BPEJ). (Metodika Ocenění Půdy Pro Bonitované Půdně-Ekologické Jednotky (BPEJ)); ÚZEI, Ed.; ÚZEI: Prague, Czech Republic, 2012.

38. Voltr, V.; Bartlová, J.; Brtnický, M.; Denešová, O.; Froněk, P.; Honz, J.; Hlavsa, T.; Hruška, M.; Khel, T.; Kohút, M.; et al. Evaluation of Land in Environmental Conditions (Hodnocení Pi̊dy v Podminkách Ochrany Životního Prostředí); ÚZEI: Prague, Czech Republic, 2012; ISBN 978-80-86671-86-4.

39. Voltr, V.; Hruška, M.; Nobilis, L.; Fuksa, P.; Pokorný, J. Procedure of Economic, Energy and Environmental Evaluation of Crop Production in the Czech Republic. Eur. Biomass Conf. Exhib. Proc. 2020, 251409, 55-61. [CrossRef] 
40. Jansky, J.; Zivelova, I.; Polackova, J.; Boudny, J.; Redlichova, R. Trend Analysis of Revenues and Costs within the Chosen Commodities under the Conditions of Organic Agriculture. ZEMED. EKON. PRAHA 2006, 52, 437. Available online: https: / / doi.org/10.17221/5047-AGRICECON (accessed on 3 March 2021).

41. Voltr, V. Emission of Pesticides. Available online: https://www.uzei.cz/data/usr_001_cz_soubory/210218_pesticides_emission. pdf (accessed on 18 February 2021).

42. Camargo, G.G.T.; Ryan, M.R.; Richard, T.L. Energy Use and Greenhouse Gas Emissions from Crop Production Using The Farm Energy Analysis Tool. Bioscience 2013, 63, 263-273. [CrossRef]

43. Voltr, V. Emissions of Annorganic Fertilizers. Available online: https://www.uzei.cz/data/usr_001_cz_soubory/210218 _Anorganic_fertilizers_emission.pdf (accessed on 18 February 2021).

44. Voltr, V. Emission of Organic Fertilizers. Available online: https://www.uzei.cz/data/usr_001_cz_soubory/210218_organic_ fertilizers.pdf (accessed on 18 February 2021).

45. Voltr, V. Diesel Emission. Available online: https://www.uzei.cz/data/usr_001_cz_soubory/210218_Diesel_emission.pdf (accessed on 18 February 2021).

46. Huijbregts, M.A.J.; Steinmann, Z.J.N.; Elshout, P.M.F.; Stam, G.; Verones, F.; Vieira, M.; Zijp, M.; Hollander, A.; Van Zelm, R. ReCiPe2016: A harmonised life cycle impact assessment method at midpoint and endpoint level. Comment. Discuss. Artic. 2017, 22, 138-147. [CrossRef]

47. Gallardo-Carrera, A.; Léonard, J.; Duval, Y.; Dürr, C. Effects of seedbed structure and water content at sowing on the development of soil surface crusting under rainfall. Soil Tillage Res. 2007, 95, 207-217. [CrossRef]

48. Nunes, M.R.; Karlen, D.L.; Denardin, J.E.; Cambardella, C.A. Corn root and soil health indicator response to no-till production practices. Agric. Ecosyst. Environ. 2019, 285, 106607. [CrossRef]

49. Baker, J.M.; Ochsner, T.E.; Venterea, R.T.; Griffis, T.J. Tillage and soil carbon sequestration-What do we really know? Agric. Ecosyst. Environ. 2007, 118, 1-5. [CrossRef]

50. Lhotský, J. Soil Compaction and Measures Against it. System of Measures for the Reclamation of Agricultural Land (Zhutňování Půd a Opatření Proti Němu. Soustava Opatření ke Zúrodňování Zemědělských Půd); ÚVTIZ: Prague, Czech Republic, 1984.

51. Yu, S.; Tao, J. Economic, energy and environmental evaluations of biomass-based fuel ethanol projects based on life cycle assessment and simulation. Appl. Energy 2009, 86, S178-S188. [CrossRef]

52. Hanegraaf, M.; Bioenergy, E.B.-B. Undefined Assessing the ecological and economic sustainability of energy crops. Biomass Bioenergy 1998, 15, 345-355. [CrossRef]

53. Ren, J.; Yu, P.; Xu, X. Straw utilization in China-status and recommendations. Sustainability 2019, 11, 1762. [CrossRef]

54. Dornburg, V.; Termeer, G.; Faaij, A.P.C. Economic and greenhouse gas emission analysis of bioenergy production using multiproduct crops-Case studies for the Netherlands and Poland. Biomass Bioenergy 2005, 28, 454-474. [CrossRef]

55. Börjesson, P.; Prade, T.; Lantz, M.; Björnsson, L. Energy crop-based biogas as vehicle fuel-the impact of crop selection on energy efficiency and greenhouse gas performance. Energies 2015, 8, 6033-6058. [CrossRef]

56. Arodudu, O.; Helming, K.; Wiggering, H.; Voinov, A. Bioenergy from low-intensity agricultural systems: An energy efficiency analysis. Energies 2017, 10, 29. [CrossRef]

57. Place, S.E.; Mitloehner, F.M. Beef production in balance: Considerations for life cycle analyses. Meat Sci. 2012, 92, $179-181$. [CrossRef] [PubMed]

58. Cooprider, K.L.; Mitloehner, F.M.; Famula, T.R.; Kebreab, E.; Zhao, Y.; van Eenennaam, A.L. Feedlot efficiency implications on greenhouse gas sustainability. J. Anim. Sci. 2011, 89, 2643-2656. [CrossRef]

59. Place, S.E.; Stackhouse, K.R.; Wang, Q.; Mitloehner, F.M. Mitigation of greenhouse gas emissions from U.S. beef and dairy production systems. In Understanding Greenhouse Gas Emissions from Agricultural Management; ACS Symposium Series; American Chemical Society Publications: Washington, DC, USA, 2011; Volume 1072, pp. 443-457. [CrossRef]

60. Voltr, V.; Hruška, M.; Havelka, F. Comparison of the energy and economic balance of crop production. Agric. Eng. Int. CIGR J. 2020, 22, 138-150.

61. Fathollahi, H.; Mousavi-Avval, S.H.; Akram, A.; Rafiee, S. Comparative energy, economic and environmental analyses of forage production systems for dairy farming. J. Clean. Prod. 2018, 182, 852-862. [CrossRef]

62. Wurster, P.; Maneta, M.; Beguería, S.; Cobourn, K.; Maxwell, B.; Silverman, N.; Ewing, S.; Jensco, K.; Gardner, P.; Kimball, J.; et al. Characterizing the impact of climatic and price anomalies on agrosystems in the northwest United States. Agric. For. Meteorol. 2020, 280, 107778. [CrossRef]

63. Stinner, W.; Schmalfuß, T. Perennial and Intercrop Legumes as Energy Crops for Biogas Production; Springer: Singapore, 2018; pp. 139-171. [CrossRef]

64. Hakl, J.; Fuksa, P.; Konečná, J.; Plant, L.P. Effect of applied cultivation technology and environmental conditions on lucerne farm yield in the Central Europe. Plant Soil Environ. 2014, 60, 475-480. [CrossRef]

65. Peterson, G.A.; Schlegel, A.J.; Tanaka, D.L.; Jones, O.R. Precipitation Use Efficiency as Affected by Cropping and Tillage Systems. J. Prod. Agric. 1996, 9, 180-186. [CrossRef]

66. Chameides, W.L.; Yu, H.; Liu, S.C.; Bergin, M.; Zhou, X.; Mearns, L.; Wang, G.; Kiang, C.S.; Saylor, R.D.; Luo, C.; et al. Case study of the effects of atmospheric aerosols and regional haze on agriculture: An opportunity to enhance crop yields in China through emission controls? Proc. Natl. Acad. Sci. USA 1999, 96, 13626-13633. [CrossRef] [PubMed] 
67. Voltr, V.; Klir, J.; Hruška, M. Soil productivity and its relation to the environment in the Czech Republic. In Proceedings of the IOP Conference Series: Earth and Environmental Science, Hangzhou, China, 26-29 June 2018; Volume 185.

68. A European Green Deal I European Commission. Available online: https://ec.europa.eu/info/strategy/priorities-2019-2024/ european-green-deal_en (accessed on 18 February 2021).

69. Liberalisation of the Energy Market (Electricity and Gas) IEnergy. Available online: https://ec.europa.eu/energy/content/ liberalisation-energy-market-electricity-and-gas_en (accessed on 18 February 2021). 